\title{
The PIA1/A2 Polymorphism of Glycoprotein IIla as a Risk Factor for Myocardial Infarction: A Meta-Analysis
}

\author{
Christopher N. Floyd, Agnesa Mustafa, Albert Ferro*
}

Department of Clinical Pharmacology, Cardiovascular Division, British Heart Foundation Centre of Research Excellence, King's College London, London, United Kingdom

\begin{abstract}
Background: The PIA2 polymorphism of glycoprotein IIla (GPIIla) has been previously identified as being associated with myocardial infarction (MI), but whether this represents a true association is entirely unclear due to differences in findings from different studies. We performed a meta-analysis to evaluate whether this polymorphism is a risk factor for MI.

Methods: Electronic databases (MEDLINE and EMBASE) were searched for all articles evaluating genetic polymorphisms of GPIIla. For studies where acute coronary events were recorded in association with genetic analysis, pooled odds ratios (ORs) were calculated using fixed-effects and random-effects models. The primary outcome measure was Ml, and a secondary analysis was also performed for acute coronary syndromes (ACS) more generally.

Findings: 57 studies were eligible for statistical analysis and included 17,911 cases and 24,584 controls. Carriage of the PIA2 allele was significantly associated with $\mathrm{MI}(n=40,692 ;$ OR $1.077,95 \% \mathrm{Cl} 1.024-1.132 ; \mathrm{p}=0.004)$ but with significant publication bias $(p=0.040)$. The degree of association with $\mathrm{Ml}$ increased with decreasing age of subjects ( $\leq 45$ years old: $n=9,547 ;$ OR $1.205,95 \% \mathrm{Cl} 1.067-1.360 ; \mathrm{p}=0.003$ ) and with adjustment of data for conventional cardiovascular risk factors $(n=12,001$; OR $1.240,95 \% \mathrm{Cl} 1.117-1.376 ; \mathrm{p}<0.001)$. There was a low probability of publication bias for these subgroup analyses (all $\mathrm{p}<0.05)$.

Conclusions: The presence of significant publication bias makes it unclear whether the association between carriage of the PIA2 allele and $\mathrm{MI}$ is true for the total population studied. However for younger subjects, the relative absence of conventional cardiovascular risk factors results in a significant association between carriage of the PIA2 allele and MI.
\end{abstract}

Citation: Floyd CN, Mustafa A, Ferro A (2014) The PIA1/A2 Polymorphism of Glycoprotein Illa as a Risk Factor for Myocardial Infarction: A Meta-Analysis. PLOS ONE 9(7): e101518. doi:10.1371/journal.pone.0101518

Editor: Andreas Zirlik, University Heart Center Freiburg, Germany

Received January 7, 2014; Accepted June 6, 2014; Published July 2, 2014

Copyright: (C) 2014 Floyd et al. This is an open-access article distributed under the terms of the Creative Commons Attribution License, which permits unrestricted use, distribution, and reproduction in any medium, provided the original author and source are credited.

Funding: This work was funded by Guy's \& St Thomas' Charity. The funders had no role in study design, data collection and analysis, decision to publish, or preparation of the manuscript.

Competing Interests: The authors have declared that no competing interests exist.

* Email: albert.ferro@kcl.ac.uk

\section{Introduction}

The fibrinogen receptor is the most abundant integrin on the platelet surface [1], and through binding a combination of fibrinogen, von Willebrand factor and fibronectin, its main function is to terminate haemorrhage following vascular injury. Despite this important physiological function, it also plays a pathological role when stimulated excessively or inappropriately, and is a principal mediator of acute coronary thrombosis [2].

The glycoprotein IIIa (GPIIIa) subunit of the fibrinogen receptor has a number of stable allelic variants resulting from single amino acid substitutions [3], of which the PlA1/A2 diallelic antigen system (involving a leucine-proline polymorphism at position 33, which alters the protein conformation and spatial orientation of the ligand-binding region) has been associated with an increased prevalence of cardiovascular disease. In 1996, Weiss et al reported an association between carriage of the PlA2 allele and cardiovascular disease, with the association most marked in subjects with unstable angina or myocardial infarction (MI) under 60 years of age (Odds ratio (OR) 6.2, 95\% confidence interval $(\mathrm{CI})$ $1.8-22.4 ; \mathrm{p}=0.002)$ [4]. The subsequent literature has demonstrated marked inter-study variation in the level - and indeed presence - of such an association, which in part reflects generally underpowered investigations of an allele with a frequency in Caucasian populations of approximately 15 per 100 [5], falling to 1 per 100 in Oriental populations [6].

A number of meta-analyses have investigated the association between carriage of the PlA2 allele and cardiovascular disease. In 2001 Di Castelnuovo et al identified a significant association between PIA2 carriage and coronary artery disease $(n=17,049$; OR 1.10, 95\% CI 1.03-1.18), but found no significant association with MI $(n=11,628$; OR 1.09, 95\% CI 0.97-1.22) [7]. A subsequent meta-analysis also found no association with either MI $(n=30,630$; per-allele RR $1.02,95 \%$ CI $0.96-1.07)$ or coronary stenosis $(n=12,741$; per-allele RR 1.04 , 95\% CI $0.97-$ 1.13) [8].

The identification of a contribution by a single gene polymorphism to a multifactorial, polygenic pathological process is challenging and requires a very large sample size [9]. Here we present the largest meta-analysis to date, involving 42,495 subjects, to address the question of whether carriage of the PlA2 polymorphism is an independent risk factor for acute coronary events. 


\section{Methods}

\section{Search strategy and selection criteria}

Electronic databases (MEDLINE and EMBASE) were searched without language restriction up until $1^{\text {st }}$ April 2013 for all articles evaluating genetic polymorphisms in the platelet GPIIIa receptor. The Medical Subject Headings terms used for the primary search related to genetics (e.g. 'gene', 'polymorphism', 'mutation' and 'genotype') in combination with glycoprotein IIIa (e.g. 'glycoprotein IIIa', 'GP IIIa' and 'integrin beta 3'). Following removal of duplicates, a total of 2,288 articles were identified in the primary search. To further encompass all relevant literature, a secondary search of the references from reviews and included studies was performed.

All articles that investigated the association between carriage of the PlA2 polymorphism and acute coronary syndromes (ACS) were considered potentially eligible for inclusion and, based on analysis of title and abstract, 114 potentially suitable articles were identified. For inclusion into the meta-analysis, studies must have reported the distribution of the $\mathrm{PlA} 1 / \mathrm{A} 2$ genotype in relation to the prevalence of a coronary event, either as raw data or calculated ORs. Both case-control and cohort studies were considered, with familial-based studies and studies without an English translation excluded.

A number of studies were not suitable for inclusion based on the following reasons: 12 studies were unavailable in English [10-21], three studies were familial-based [22-24], seven studies reported data that duplicated or overlapped with larger studies that were eligible for inclusion [25-31], 26 studies did not contain suitable outcome data [32-57], and in 11 studies all subjects had a coronary event and so there was no control population [58-68]. Following the addition of three studies identified in the secondary search [69-71], a total of 57 studies met the inclusion criteria for statistical analysis (Figure 1).

\section{Data extraction}

Data were extracted from each study according to a predefined protocol: study design, number of cases/controls, geographic location and/or ethnicity, sex and clinical outcome. The primary

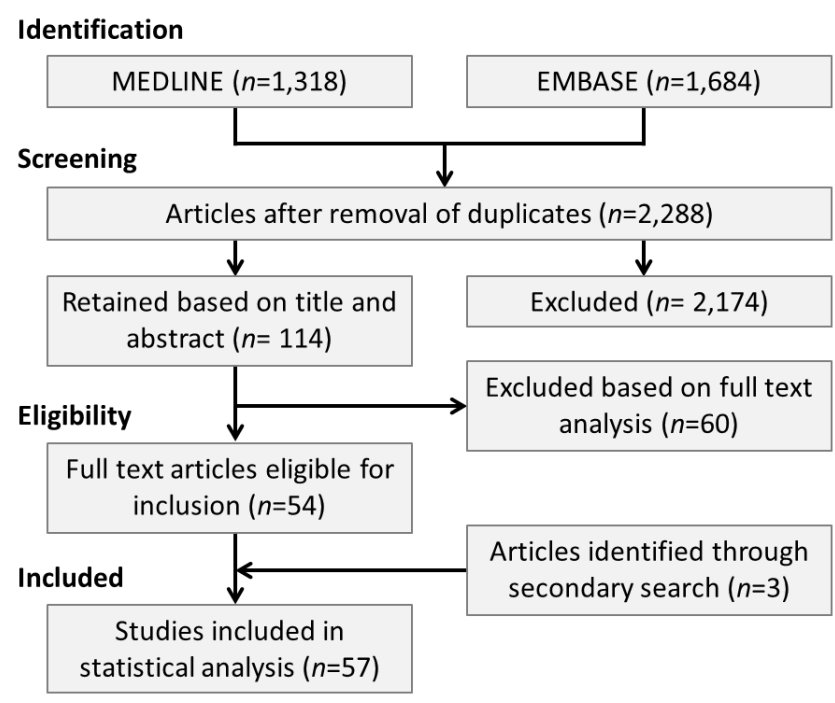

Figure 1. Summary of strategy used to identify studies suitable for analysis.

doi:10.1371/journal.pone.0101518.g001 outcome measure was MI with a secondary outcome being ACS more generally. For the secondary outcome measure, data on the incidence of ACS were included preferentially where MI incidence was also reported.

Ethnic group was recorded where explicitly stated within a study. Where genotype information was reported for $>1$ subpopulation as defined by geographic region or ethnic origin, each sub-population was considered separately in the analyses [9]. This was the case for studies by Herrmann et al and Kekomaki et al [72,73].

Where data adjusted for age, gender, ethnicity and cardiovascular risk factors were available, these were analysed in preference to raw data. Similarly, in studies which had more than one control group, subjects with coronary artery disease were used in preference to healthy subjects as controls.

\section{Statistical analysis}

Data were analysed using Comprehensive Meta-analysis software, version 2 (Biostat, USA). Pooled ORs were calculated using fixed- and random-effects models, along with the 95\% CI to measure the strength of association. Fixed-effects summary ORs were calculated using the Mantel-Haenszel method [74], and the DerSimonian method was used to calculate random-effects summary Ors [75]. For data where more than one outcome was reported, combined effects were calculated as necessary [76]. Pooled ORs presented in the results were calculated using the fixed-effects model unless otherwise stated.

Tests for heterogeneity were performed for each meta-analysis, with significance set at $\mathrm{p}<0.05$ [77]. $\mathrm{I}^{2}$ was also calculated for each analysis, where $\geq 50 \%$ may represent substantial heterogeneity [78]. For assessment of publication bias, we utilised a funnel plot and Egger's regression asymmetry test [79]. In addition, the effect of individual studies on the summary OR was evaluated by reestimating and plotting the summary $\mathrm{OR}$ in the absence of each study.

\section{Results}

We identified 53 studies with the endpoint of myocardial infarction, comprising a total of 16,863 cases and 23,829 controls. Pooled OR for the association of carriage of the PlA2 allele (PlA1/ A2+PlA2/A2 versus PlA1/A1 genotype) with MI was significant at 1.077 (95\% CI 1.024-1.132; $\mathrm{p}=0.004$ ) (Figure 2) [70-73,80-128]. Significant heterogeneity was observed $\left(\mathrm{I}^{2}=57.9 \% ; \mathrm{p}<0.001\right)$, and analysis using the random-effects model increased the degree of association (OR 1.132, 95\% CI 1.039-1.232; $\mathrm{p}=0.004$ ). The addition of three further studies to assess the association with ACS more generally yielded an OR of $1.074(n=42,426 ; 95 \%$ CI 1.023-1.127; $\mathrm{p}=0.004$ ) (Table 1) $[4,69,129]$.

Analysis of the association between carriage of the PlA2 allele and MI using data adjusted for age, sex, ethnicity and cardiovascular risk factors demonstrated an increased level of association $(n=12,001$; OR 1.240, 95\% CI 1.117-1.376; $\mathrm{p}<$ 0.001) [87,88,96,97,101,109,110,112,119-121,125,127]. Further subgroup analysis based on comparison of the PlAl/Al versus PlA2/A2 genotype failed to show a significant association $(n=23,836 ; \quad$ OR $1.023, \quad 95 \% \quad$ CI $\quad 0.877-1.192 ; \quad \mathrm{p}=0.774)$ [70-72,81,82,86-91,95,98-100,102-104,106-108,111-114,116,117, 120,122,124,128] (Figure 3); however, within this analysis, the number of subjects with the PlA2/A2 genotype was small, consisting of 333 cases and 1,504 controls. 
Study name

Addad et al, 2010

Anderson et al, 1999

Ardissino et al, 1999

Auguardo et al, 2002

Benze et al, 2002

Boekholdt et al, 2004

Bojesen et al, 2003

Bottiger et al, 2000

Carter et al, 1997

Corral et al, 1997

Dayakar et al, 2011

Dogra et al, 2012

Durante-Mangoni et al, 1998

Faraday et al, 2004

Galasso et al, 2010

Gardemann et al, 1998

Grove et al, 2004

Gruchala et al, 2003

Herrmann et al, 1997*

Herrmann et al, 1997*

Hooper et al, 1999

Joven et al, 1998

Kastrati et al, 2000

Kekomaki et al, 1999*

Kekomaki et al, 1999*

Knowles et al, 2007

Kozieradzka et al, 2006

Kozieradzka et al, 2007

Lagercrantz et al, 2003

Lopez et al, 2004

Mamotte et al, 1998

Mannucci et al, 2003

Marian et al, 1996

Marz et al, 2004

Moshfegh et al, 1999

Motovska et al, 2010

Musino et al, 2010

Nikolajevic-Starcevic et al, 2012

Osborn et al, 1996

Park et al, 2004

Pastinen et al, 1998

Pegoraro et al, 2005

Ridker et al, 1997

Rinder et al, 2002

Rosenberg et al, 2002

Samani et al, 1997

Santiago-German et al, 2012

Scaglione et al, 1998

Schwartz et al, 2003

Senti et al, 1998

Smith et al, 2003

Tobin et al, 2004

Walter et al, 2001

Zotz et al, 1998

Zotz et al, 2005

Pooled results
Degree of adjustment
OR (fixed) and $95 \% \mathrm{Cl}$

Odds Lower Upper

ratio limit limit

$\begin{array}{lll}0.570 & 0.304 & 1.067\end{array}$

$\begin{array}{lll}1.502 & 1.010 & 2.233\end{array}$

$\begin{array}{lll}1.843 & 1.154 & 2.946\end{array}$

$\begin{array}{lll}1.760 & 0.969 & 3.196\end{array}$

$\begin{array}{lll}2.007 & 1.177 & 3.421\end{array}$

$\begin{array}{lll}1.026 & 0.676 & 1.555\end{array}$

$\begin{array}{lll}1.048 & 0.859 & 1.279\end{array}$

$\begin{array}{lll}1.060 & 0.791 & 1.421\end{array}$

$\begin{array}{lll}1.660 & 1.151 & 2.393\end{array}$

$\begin{array}{lll}0.717 & 0.367 & 1.398\end{array}$

$\begin{array}{lll}5.935 & 3.398 & 10.366\end{array}$

$\begin{array}{llr}1.123 & 0.683 & 1.845\end{array}$

$\begin{array}{lll}0.588 & 0.249 & 1.388\end{array}$

$\begin{array}{lll}0.706 & 0.338 & 1.477\end{array}$

$\begin{array}{lll}1.428 & 0.740 & 2.755\end{array}$

$\begin{array}{lll}0.934 & 0.775 & 1.126\end{array}$

$\begin{array}{rlll} & 0.490 & 1.017 & 2.183 \\ + & 1.40\end{array}$

$\begin{array}{llll}++ & 1.120 & 0.700 & 1.791\end{array}$

$\begin{array}{llll}- & 0.975 & 0.736 & 1.292\end{array}$

$\begin{array}{lll}1.110 & 0.702 & 1.754\end{array}$

$\begin{array}{lll}0.733 & 0.401 & 1.341\end{array}$

$\begin{array}{lll}1.092 & 0.756 & 1.579\end{array}$

$\begin{array}{lll}0.993 & 0.795 & 1.239\end{array}$

$\begin{array}{lll}1.609 & 0.595 & 4.351\end{array}$

$\begin{array}{lll}1.185 & 0.555 & 2.529\end{array}$

$\begin{array}{lll}1.260 & 0.975 & 1.628\end{array}$

$\begin{array}{lll}1.385 & 0.800 & 2.397\end{array}$

$\begin{array}{lll}1.035 & 0.607 & 1.765\end{array}$

$\begin{array}{lll}0.776 & 0.565 & 1.065\end{array}$

$\begin{array}{lll}1.113 & 0.735 & 1.685\end{array}$

$\begin{array}{lll}0.956 & 0.656 & 1.394\end{array}$

$\begin{array}{lll}0.929 & 0.777 & 1.109\end{array}$

$0.945 \quad 0.520 \quad 1.719$

$\begin{array}{rrr}0.945 & 0.520 & 1.719 \\ +\quad 1.090 & 0.869 & 1.368\end{array}$

$\begin{array}{llll}- & 0.912 & 0.493 & 1.688\end{array}$

$\begin{array}{llll}++ & 0.993 & 0.548 & 1.800\end{array}$

\begin{tabular}{llll}
+ & 1.298 & 0.719 & 2.341 \\
\hline & 1.008 & 0.570 & 1.782
\end{tabular}

$\begin{array}{llll}++ & 1.008 & 0.570 & 1.782\end{array}$

$\begin{array}{lll}1.109 & 0.559 & 2.202\end{array}$

$0.836 \quad 0.591 \quad 1.182$

$\begin{array}{lll}2.110 & 1.238 & 3.596\end{array}$

$\begin{array}{lll}0.920 & 0.575 & 1.473\end{array}$

$0.935 \quad 0.701 \quad 1.246$

$\begin{array}{lll}1.500 & 0.517 & 4.352\end{array}$

$\begin{array}{lll}1.190 & 0.567 & 2.497\end{array}$

\begin{tabular}{llll}
++ & 1.190 & 0.567 & 2.497 \\
+ & 0.890 & 0.579 & 1.368 \\
\hline
\end{tabular}

$\begin{array}{llll}+ & 0.890 & 0.579 & 1.368 \\ + & 2.340 & 1.613 & 3.395 \\ + & 0.767 & 0.404 & 1.455\end{array}$

$\begin{array}{llll}++ & 2.340 & 1.613 & 3.395 \\ - & 0.767 & 0.404 & 1.455\end{array}$

$\begin{array}{llll} & \\ - & 1.848 & 1.141 & 2.993\end{array}$

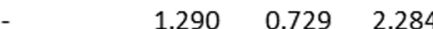

$\begin{array}{llll}++ & 0.800 & 0.432 & 1.481\end{array}$

$\begin{array}{llll}- & 0.829 & 0.640 & 1.074\end{array}$

$\begin{array}{llll}- & 1.302 & 0.839 & 2.020\end{array}$

$\begin{array}{llll}++ & 1.500 & 0.919 & 2.449\end{array}$

$\begin{array}{lll}0.940 & 0.787 & 1.123\end{array}$

$\begin{array}{lll}1.077 & 1.024 & 1.132\end{array}$

Test for heterogeneity: $Q$-value $=128.346, d f=54(p<0.001) ;\left.\right|^{2}=57.9 \%$ Test for overall effect: $Z=2.900(p=0.004)$

OR (fixed) and $95 \% \mathrm{Cl}$

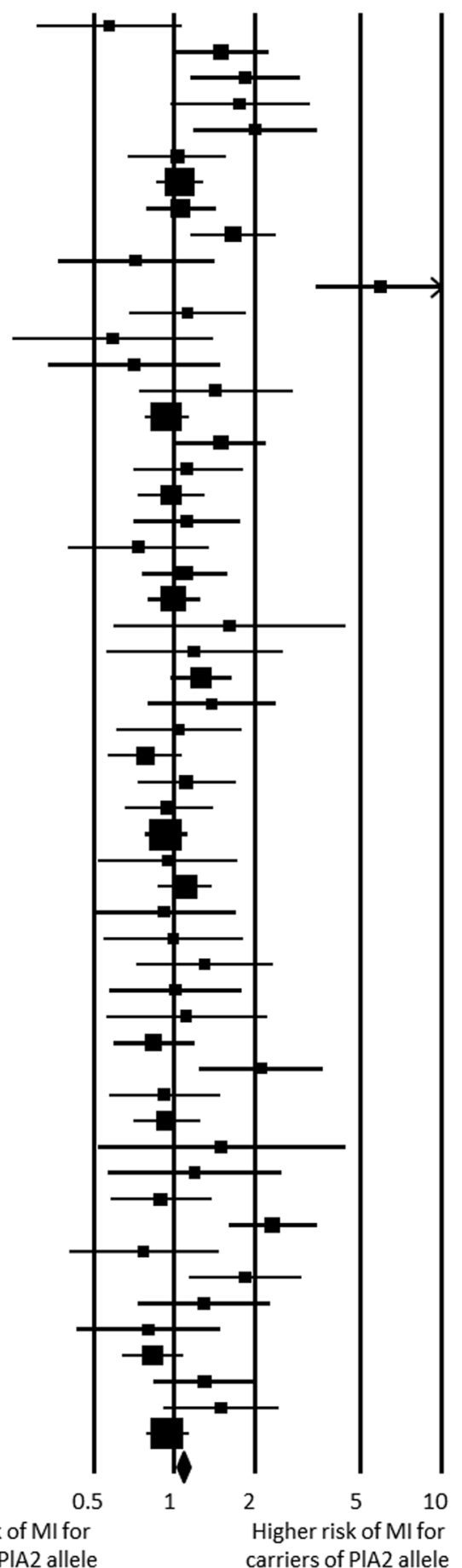

* Studies by Herrmann et al and Kekomaki et al contained distinct population subgroup therefore data processed independently

- No adjustment of data

+ Adjustment of data for gender, age and/or ethnicity

++ Adjustment of data for gender, age and/or ethnicity, plus conventional cardiovascular risk factors

[OR = odds ratio; $\mathrm{Cl}=$ confidence interval; $\mathrm{Ml}=$ myocardial infarction $]$

Figure 2. Analysis of the association between carriage of the PIA2 allele and myocardial infarction. Analysis is of the PIA1/A1 versus PIA1/A2+PIA2/A2 genotype.

doi:10.1371/journal.pone.0101518.g002 
Table 1. Association between carriage of the PIA2 polymorphism and acute coronary events.

\begin{tabular}{|c|c|c|c|c|c|}
\hline & Number of studies & $\begin{array}{l}\text { Number of cases/ } \\
\text { controls }\end{array}$ & $\begin{array}{l}\text { Pooled OR* } \\
(95 \% \mathrm{CI})\end{array}$ & $\begin{array}{l}\text { Association } \\
\text { (p value) }\end{array}$ & $I^{2}(\%)$ \\
\hline \multicolumn{6}{|l|}{ Primary analysis: } \\
\hline \multirow[t]{2}{*}{ MI } & 53 & $16,863 / 23,829$ & 1.077 & 0.004 & 57.9 \\
\hline & {$[70-73,80-128]$} & & $(1.024-1.132)$ & & \\
\hline \multicolumn{6}{|c|}{ Secondary and subgroup analyses: } \\
\hline \multirow[t]{2}{*}{ ACS } & 56 & $17,887 / 24,539$ & 1.074 & 0.004 & 59.3 \\
\hline & {$[4,69-73,80-129]$} & & $(1.023-1.127)$ & & \\
\hline \multirow[t]{2}{*}{ MI (adjusted data) } & 13 & $6,188 / 5,813$ & 1.240 & $<0.001$ & 47.6 \\
\hline & {$[87,88,96,97,101,109,110,112,119-121,125,127]$} & & $(1.117-1.376)$ & & \\
\hline \multirow[t]{2}{*}{$\mathrm{PIA} 1 / \mathrm{A} 1$ vs $\mathrm{PIA} 2 / \mathrm{A} 2$} & 31 & $7,245 / 16,591$ & 1.023 & 0.287 & 40.8 \\
\hline & $\begin{array}{l}{[70-72,81,82,86-91,95,98-100,102-104,106-} \\
108,111-114,116,117,120,122,124,128]\end{array}$ & & $(0.877-1.192)$ & & \\
\hline
\end{tabular}

*OR (odds ratio) calculated using fixed-effects model for carriage of the PIA2 allele vs PIA1 homozygous subjects.

$[\mathrm{MI}=$ myocardial infarction; $\mathrm{ACS}=$ acute coronary syndrome $]$.

doi:10.1371/journal.pone.0101518.t001

\section{Subgroup analyses based on subject demographics}

Data were available to calculate pooled ORs based on subject ethnicity, sex and age (Table 2). Analysis based on ethnicity was limited to Caucasians as the majority of studies did not explicitly state the ethnicity of participants. A non-significant pooled OR for the association of PlA2 carriage with MI was observed for the 11 available studies $(n=10,585$; OR $1.050,95 \%$ CI $0.962-1.146$; $\mathrm{p}=0.272)[71,81,88,95-97,103,109,112,127,128]$.

The association between PlA2 carriage and MI in male subjects was observed to be consistent with the primary analysis $(n=8,686$; OR $1.145, \quad 95 \%$ CI $\quad 1.018-1.288 ; \quad \mathrm{p}=0.024) \quad[72,84$ $86,97,99,114,115,120,123,127]$. Only two studies provided data for female subjects, resulting in no significant association observed in these $(n=5,237$; OR $0.961,95 \%$ CI $0.703-1.312$; $\mathrm{p}=0.801)$ $[86,120]$.

Subgroup analyses based on subject age at first MI demonstrated an increased level of association with decreasing age (Figure 4). For subjects $\leq 45$ years old, carriage of the PlA2 allele produced a pooled OR for MI of $1.205(n=9,547$; 95\% CI $1.067-$ $1.360 ; \mathrm{p}=0.003)$ with significant heterogeneity $\left(\mathrm{I}^{2}=70.3 \%, \mathrm{p}<\right.$ $0.001)$, and analysis using the random-effects model again increased the level of association (OR 1.356, 95\% CI 1.044 1.762; p $=0.022) \quad[72,82,84,86,91,97,107,116,121-123]$. Significant heterogeneity and an increased level of association as compared with the total population were also observed using the random-effects model for the $\leq 55$ and $\leq 65$ year-old subgroups.

In 15 of the studies identified, the recorded cardiovascular event was a 'first event' for the participant. Analysis of these studies revealed an association between carriage of the PlA2 allele and MI that was stronger than that seen in the primary analysis $(n=18,349 ; \quad$ OR $1.131, \quad 95 \%$ CI $1.036-1.234 ; \quad \mathrm{p}=0.006)$ [82,84,86,87,90,101,104,107,111,117,119-122,124,125].

\section{Subgroup analyses based on study characteristics}

As described within the Methods, adjusted data were analysed in preference to raw data wherever possible in order to distinguish the true effect of the PlA2 allele against a background of conventional cardiovascular risk factors. Similarly, in studies where more than one control population was included, the group with coronary artery disease was selected in preference to healthy subjects as the control group. These data are all displayed in Table 3. Subgroup analysis of crude data using only healthy controls found an increased association between PlA2 carriage and MI compared to the primary analysis $(n=29,907$; OR $1.098,95 \%$ CI $1.033-1.166 ; \quad p=0.003) \quad[71-73,81-84,86-91,96,98,99,102-$ 104,107,108,110-113,115-117,119-125,127,128], whereas analysis of raw data using controls with known coronary artery disease found no significant association $(n=11,819 ; 95 \%$ CI $0.941-1.114$; $\mathrm{p}=0.583) \quad($ Figure 5) $[80,85,87,88,92-94,96,100,105,106,108$, 114,118,126-128].

Study design was found to influence the degree of association. Cohort studies did not demonstrate an association between carriage of the PlA2 allele and MI $(n=19,032$; OR 0.996, 95\% CI $\quad 0.917-1.082 ; \quad p=0.926) \quad[80,85,86,92-95,97,100,105,106$, $109,112,114,118,125,126]$, whereas case-control studies did $(n=21,660 ;$ OR 1.126, 95\% CI 1.057-1.198; $\mathrm{p}<0.001)$ (Figure 6) [70-73,81-84,87-91,96,98,99,101-104,107,108,110,111,113,115$117,119-124,127,128]$. Studies with $<250$ cases showed a significant association $(n=10,145$; OR $1.240,95 \%$ CI $1.139-1.350$; $\mathrm{p}=0.006) \quad[70,72,73,80-83,85,88-94,97,98,102,103,105,108,110$, $111,113-116,118-127,130]$, whereas studies with $\geq 250$ cases did not $(n=30,547 ;$ OR $0.999,95 \%$ CI $0.935-1.084 ; \mathrm{p}=0.864)$ [71,72,84,86,87,95,96,99-101,104,106,107,109,112,117,128].

Eleven out of 17 studies with $\geq 250$ cases were case-control studies $[71,72,84,87,99,101,104,107,117,120,128]$.

\section{Publication bias}

Publication bias was assessed by plotting funnel plots and calculation of Egger's regression intercept. The funnel plot for the primary analysis was asymmetric with a significant Egger's regression intercept $(p=0.040)$, suggesting the likelihood of publication bias skewed towards studies that favour an association between carriage of the PlA2 allele and MI (Figure 7). This bias was independent of study size $(<250$ cases, $p=0.264 ; \geq 250$ cases, $\mathrm{p}=0.088$ ), but dependent on study design (case-control studies, $\mathrm{p}=0.021$; cohort studies, $\mathrm{p}=0.570)$. Further analysis of case- 
Study name

Anderson et al, 1999

Ardissino et al, 1999

Bojesen et al, 2003

Carter et al, 1997

Dayakar et al, 2011

Dogra et al, 2012

Gardemann et al, 1998

Grove et al, 2004

Herrmann et al, 1997*

Herrmann et al, 1997*

Hooper et al, 1999

Joven et al, 1998

Kastrati et al, 2000

Kozieradzka et al, 2006

Kozieradzka et al, 2007

Lagercrantz et al, 2003

Mamotte et al, 1998

Mannucci et al, 2003

Marian et al, 1996

Moshfegh et al, 1999

Musino et al, 2010

Nikolajevic-Starcevic et al, 2012

Osborn et al, 1996

Park et al, 2004

Pegoraro et al, 2005

Ridker et al, 1997

Samani et al, 1997

Scaglione et al, 1998

Senti et al, 1998

Tobin et al, 2004

Zotz et al, 2005

Pooled results
Bottiger et al, 2000

OR (fixed) and $95 \% \mathrm{Cl}$

\begin{tabular}{rcr}
$\begin{array}{c}\text { Odds } \\
\text { ratio }\end{array}$ & $\begin{array}{c}\text { Lower } \\
\text { limit }\end{array}$ & \multicolumn{1}{c}{ Upper } \\
limit \\
0.603 & 0.182 & 1.994 \\
1.445 & 0.381 & 5.485 \\
1.259 & 0.750 & 2.115 \\
1.125 & 0.513 & 2.467 \\
1.267 & 0.278 & 5.774 \\
11.573 & 3.903 & 34.314 \\
1.935 & 0.270 & 13.872 \\
0.569 & 0.309 & 1.048 \\
1.470 & 0.849 & 2.547 \\
1.334 & 0.559 & 3.184 \\
0.711 & 0.156 & 3.240 \\
0.791 & 0.071 & 8.851 \\
1.718 & 0.404 & 7.309 \\
0.991 & 0.523 & 1.878 \\
0.575 & 0.126 & 2.629 \\
0.660 & 0.173 & 2.515 \\
1.537 & 0.587 & 4.024 \\
9.900 & 2.670 & 36.710 \\
0.902 & 0.565 & 1.442 \\
0.410 & 0.083 & 2.021 \\
0.739 & 0.253 & 2.161 \\
1.986 & 0.629 & 6.274 \\
0.771 & 0.449 & 1.326 \\
0.647 & 0.133 & 3.150 \\
0.722 & 0.431 & 1.207 \\
1.516 & 0.094 & 24.403 \\
0.589 & 0.248 & 1.395 \\
0.508 & 0.119 & 2.167 \\
3.733 & 0.407 & 34.216 \\
2.083 & 0.484 & 8.969 \\
0.936 & 0.434 & 2.020 \\
0.827 & 0.441 & 1.551 \\
1.023 & 0.877 & 1.192
\end{tabular}

Test for heterogeneity: $Q$-value $=52.384, d f=31(p=0.010) ; 1^{2}=40.8 \%$ Test for overall effect: $\mathrm{Z}=0.287(\mathrm{p}=0.774)$

\section{OR (fixed) and $95 \% \mathrm{Cl}$}

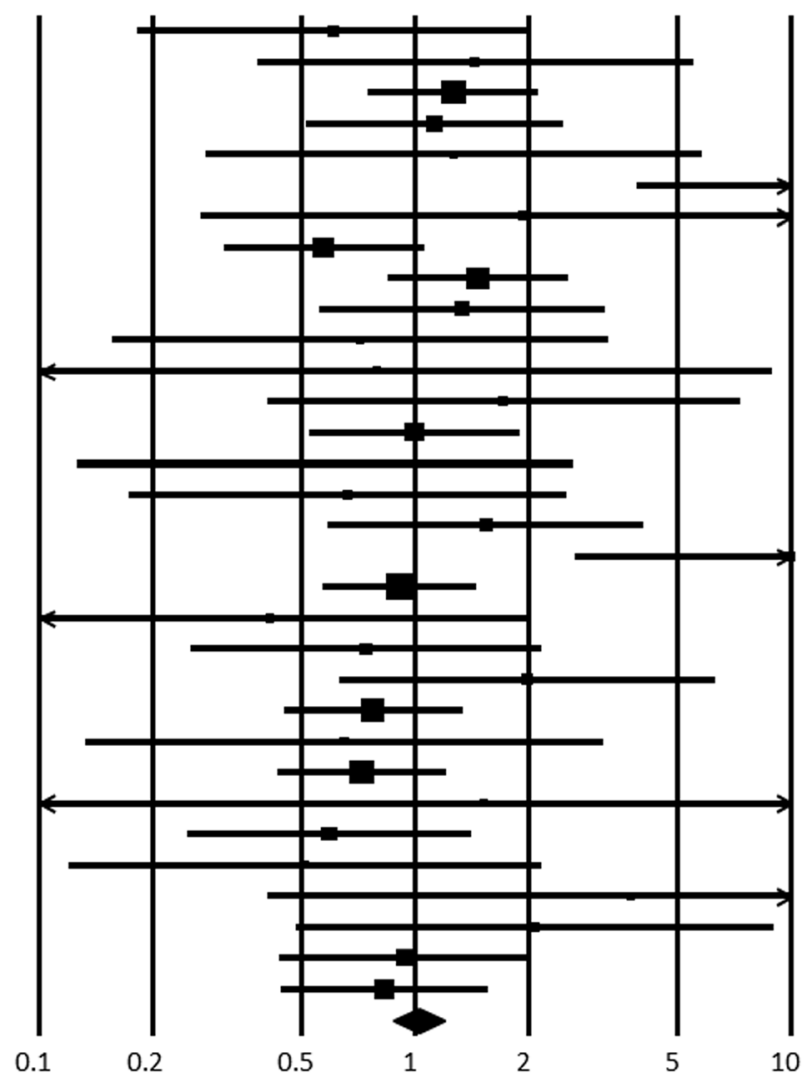

Decreased risk of $\mathrm{Ml}$ for subjects homozygous for PIA2 allele
Increased risk of MI for subjects homozygous for PIA2 allele

* Studies by Herrmann et al contained distinct population subgroups therefore data processed independently [OR = odds ratio; $\mathrm{Cl}=$ confidence interval; $\mathrm{Ml}=$ myocardial infarction $]$

Figure 3. Analysis of the association with myocardial infarction between subjects homozygous for the PIA1 allele and those homozygous for the PIA2 allele.

doi:10.1371/journal.pone.0101518.g003

control studies suggested that this bias was not associated with study size $(<250$ cases, $p=0.157 ; \geq 250$ cases, $p=0.066)$. Significant bias was not present for the subgroup analyses based on age $(\leq 65, \mathrm{p}=0.161 ; \leq 55, \mathrm{p}=0.191 ; \leq 45, \mathrm{p}=0.192)$.

\section{Discussion}

The data presented here appears to demonstrate an increased risk of MI in carriers of the PA2 allele, with an association that becomes stronger as age decreases. Significant publication bias identified in the primary analysis makes it unclear whether the association is true for the totality of the population studied. This bias is primarily driven by case-control studies and surprisingly independent of study size given that smaller studies are generally more prone to this effect. The presence of bias is consistent with the general findings of the two previous meta-analyses $[7,8]$. However despite these concerns, there remains a clear age effect with the association between carriage of the PlA2 allele and MI most evident for younger age cohorts.

The observed age-skewed risk profile may be explained by a relative (rather than absolute) decrease in the influence of genetic factors with age, given that the prevalence of conventional cardiovascular risk factors increases with age [131]. This hypothesis is supported by the increased association between carriage of the PlA2 allele and MI observed in the subgroup analysis using data adjusted for these risk factors. Similarly, subgroup analysis using unadjusted data and controls with coronary artery disease resulted in no significant association seen, and this is likely to be explained again by the dilution effect caused by the coexistence of conventional risk factors.

\section{Aetiology of increased risk}

It is unclear as to the mechanism by which carriage of PlA2 predisposes to increased cardiovascular morbidity and mortality. The aetiology of cardiovascular risk is not monogenic, but a 
Table 2. Subgroup analyses of the association between carriage of the PIA2 allele and myocardial infarction by subject demographics.

\begin{tabular}{|c|c|c|c|c|c|}
\hline & Number of studies & $\begin{array}{l}\text { Number of } \\
\text { cases/controls }\end{array}$ & $\begin{array}{l}\text { Pooled OR* } \\
(95 \% \mathrm{CI})\end{array}$ & $\begin{array}{l}\text { Association } \\
\text { (p value) }\end{array}$ & $I^{2}(\%)$ \\
\hline \multirow[t]{2}{*}{ Caucasian } & 11 & $5,047 / 5,538$ & 1.050 & 0.272 & 51.9 \\
\hline & {$[71,81,88,95-97,103,109,112,127,128]$} & & $(0.962-1.146)$ & & \\
\hline \multirow[t]{2}{*}{ Male } & 11 & $2,715 / 5,971$ & 1.145 & 0.024 & 39.0 \\
\hline & {$[72,84-86,97,99,114,115,120,123,127]$} & & $(1.018-1.288)$ & & \\
\hline \multirow[t]{2}{*}{ Female } & 2 & $249 / 4,988$ & 0.961 & 0.801 & 0.0 \\
\hline & {$[86,120]$} & & $(0.703-1.312)$ & & \\
\hline \multicolumn{6}{|c|}{ Subgroup analyses based on age of first event: } \\
\hline \multirow[t]{2}{*}{ Age $\leq 65$ years old $\uparrow$} & 23 & $5,216 / 10,952$ & 1.101 & 0.029 & 57.4 \\
\hline & {$[72,82,84,86,91,97,99,106,107,110,111,114,116,119,121-123,140]$} & & $(1.010-1.201)$ & & \\
\hline \multirow[t]{2}{*}{ Age $\leq 55$ years old ${ }^{\dagger}$} & 18 & $3,744 / 6,017$ & 1.144 & 0.007 & 58.5 \\
\hline & {$[72,82,84,86,91,97,99,106,107,110,111,114,116,119,121-123,140]$} & & $(1.037-1.261)$ & & \\
\hline \multirow[t]{2}{*}{ Age $\leq 45$ years old ${ }^{\dagger}$} & 11 & $3,675 / 5,872$ & 1.205 & 0.003 & 70.3 \\
\hline & {$[72,82,84,86,91,97,107,116,121-123]$} & & $(1.067-1.360)$ & & \\
\hline \multirow[t]{2}{*}{ First $\mathrm{MI}^{\S}$} & 15 & $5,011 / 13,338$ & 1.131 & 0.006 & 81.2 \\
\hline & {$[82,84,86,87,90,101,104,107,111,117,119-122,124,125]$} & & $(1.036-1.234)$ & & \\
\hline
\end{tabular}

*OR (odds ratio) calculated using fixed-effects model for carriage of the PIA2 allele vs PIA1 homozygous subjects.

${ }^{\dagger}$ Age defined as age of onset of event.

${ }^{s}$ Event recorded as the first $\mathrm{Ml}$ experienced by the subject.

$[\mathrm{MI}=$ myocardial infarction $]$.

doi:10.1371/journal.pone.0101518.t002

complex polygenic interaction with environmental factors [131], with each additional factor contributing in an additive and sometimes in a synergistic manner [132]. This contribution can be clearly demonstrated in the increased risk that smoking adds to carriage of the PlA2 allele when compared to non-smoking PlA1 homozygotes $[82,96,105,123]$. It has been suggested that smoking and PlA2 increase cardiovascular risk via interacting mechanisms [133], but given the strong association of smoking with premature myocardial infarction [134], further data are required to test the strength of this association.

There remains the possibility of unidentified linkage disequilibrium with genes modulating other conventional cardiac risk factors, with elevated plasma lipids being previously linked to carriage of the PlA2 allele [133]. This hypothesis is however not supported by the data analysed within the present meta-analysis, with only one study finding higher triglycerides in carriers of the PlA2 allele [80] and conflicting reports on the levels of lipoprotein(a) [86,99]. Interestingly, Grove et al found that the association between carriage of the PlA2 allele and MI decreased as cholesterol levels increased, suggesting once again that the true effect of the PlA2 allele may be diluted and hence concealed by the concomitant presence of conventional risk factors [96].

The proximity of the PlAl/A2 epitope to the ligand binding site of GPIIIa has led investigators to consider how the single amino acid substitution of proline for leucine may affect the cycle of ligand association and dissociation with the fibrinogen receptor.

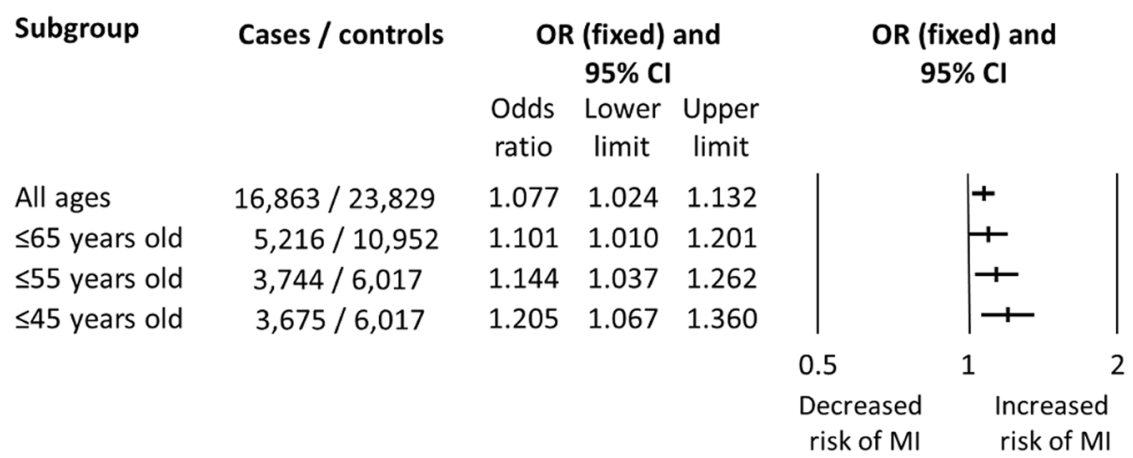

[OR = odds ratio $\mathrm{Cl}$ = confidence interval; $\mathrm{MI}=$ myocardial infarction $]$

Figure 4. Summary of subgroup analyses based on age at first event. Analysis is of the PIA1/A1 versus PIA1/A2+PIA2/A2 genotype. doi:10.1371/journal.pone.0101518.g004 
Study name

CAD controls:

Addad et al, 2010

Boekholdt et al, 2004

Bottiger et al, 2000

Carter et al, 1997

Durante-Mangoni et al, 1998

Faraday et al, 2004

Galasso et al, 2010

Grove et al, 2004

Kastrati et al, 2000

Lopez et al, 2004

Mamotte et al, 1998

Marian et al, 1996

Park et al, 2004

Rinder et al, 2002

Walter et al, 2001

Zotz et al, 1998

Zotz et al, 2005

Subgroup total
OR (fixed) and $95 \% \mathrm{Cl}$

Odds Lower Upper

ratio limit limit

$\begin{array}{lll}0.570 & 0.304 & 1.067 \\ 1.026 & 0.676 & 1.555 \\ 0.990 & 0.807 & 1.215 \\ 1.279 & 0.830 & 1.970 \\ 0.588 & 0.249 & 1.388 \\ 0.706 & 0.338 & 1.477 \\ 1.428 & 0.740 & 2.755 \\ 1.395 & 1.069 & 1.819 \\ 0.993 & 0.795 & 1.239 \\ 1.113 & 0.735 & 1.685 \\ 0.956 & 0.656 & 1.394 \\ 0.945 & 0.520 & 1.719 \\ 0.836 & 0.591 & 1.182 \\ 1.500 & 0.517 & 4.352 \\ 1.302 & 0.839 & 2.020 \\ 1.806 & 0.862 & 3.784 \\ 0.940 & 0.787 & 1.123 \\ 1.024 & 0.941 & 1.114\end{array}$

Test for heterogeneity: $Q$-value=19.776, $d f=16(p=0.230) ; 1^{2}=19.1 \%$ Test for overall effect: $Z=0.550(p=0.583)$

Healthy controls:
Anderson et al, 1999

Ardissino et al, 1999

Auguardo et al, 2002

Benze et al, 2002

Bojesen et al, 2003

Bottiger et al, 2000

Carter et al, 1997

Corral et al, 1997

Dayakar et al, 2011

Dogra et al, 2012

Grove et al, 2004

Herrmann et al, 1997*

Herrmann et al, 1997*

Hooper et al, 1999

Joven et al, 1998

Kekomaki et al, 1999*

Kekomaki et al, 1999*

Kozieradzka et al, 2006

Kozieradzka et al, 2007

Lagercrantz et al, 2003

Mannucci et al, 2003

Marian et al, 1996

Motovska et al, 2010

Musino et al, 2010

Nikolajevic-Starcevic et al, 2012

Osborn et al, 1996

Pastinen et al, 1998

Pegoraro et al, 2005

Ridker et al, 1997

Rosenberg et al, 2002

Samani et al, 1997

Santiago-German et al, 2012

Scaglione et al, 1998

Schwartz et al, 2003

Senti et al, 1998

Smith et al, 2003

Tobin et al, 2004

Zotz et al, 1998

Zotz et al, 2005

Subgroup total

$\begin{array}{llr}1.502 & 1.010 & 2.233 \\ 1.843 & 1.154 & 2.946 \\ 1.760 & 0.969 & 3.196 \\ 2.007 & 1.177 & 3.421 \\ 1.048 & 0.859 & 1.279 \\ 1.098 & 0.827 & 1.458 \\ 1.338 & 0.857 & 2.089 \\ 0.717 & 0.367 & 1.398 \\ 5.935 & 3.398 & 10.366 \\ 1.123 & 0.683 & 1.845 \\ 1.403 & 1.128 & 1.746 \\ 0.975 & 0.736 & 1.292 \\ 1.110 & 0.702 & 1.754 \\ 0.733 & 0.401 & 1.341 \\ 1.092 & 0.756 & 1.579 \\ 1.609 & 0.595 & 4.351 \\ 1.185 & 0.555 & 2.529 \\ 1.385 & 0.800 & 2.397 \\ 1.035 & 0.607 & 1.765 \\ 0.776 & 0.565 & 1.065 \\ 0.929 & 0.777 & 1.109 \\ 0.669 & 0.371 & 1.206 \\ 0.944 & 0.534 & 1.669 \\ 1.298 & 0.719 & 2.341 \\ 0.892 & 0.634 & 1.255 \\ 1.109 & 0.559 & 2.202 \\ 2.110 & 1.238 & 3.596 \\ 0.920 & 0.575 & 1.473 \\ 0.935 & 0.701 & 1.246 \\ 0.742 & 0.330 & 1.667 \\ 0.947 & 0.644 & 1.394 \\ 2.036 & 1.327 & 3.124 \\ 0.767 & 0.404 & 1.455 \\ 1.848 & 1.141 & 2.993 \\ 1.290 & 0.729 & 2.284 \\ 0.729 & 0.404 & 1.316 \\ 0.829 & 0.640 & 1.074 \\ 0.903 & 0.481 & 1.694 \\ 1.030 & 0.824 & 1.288 \\ 1.098 & 1.033 & 1.166\end{array}$

Test for overall effect: $Z=3.016(p=0.003)$
OR (fixed) and $95 \% \mathrm{Cl}$

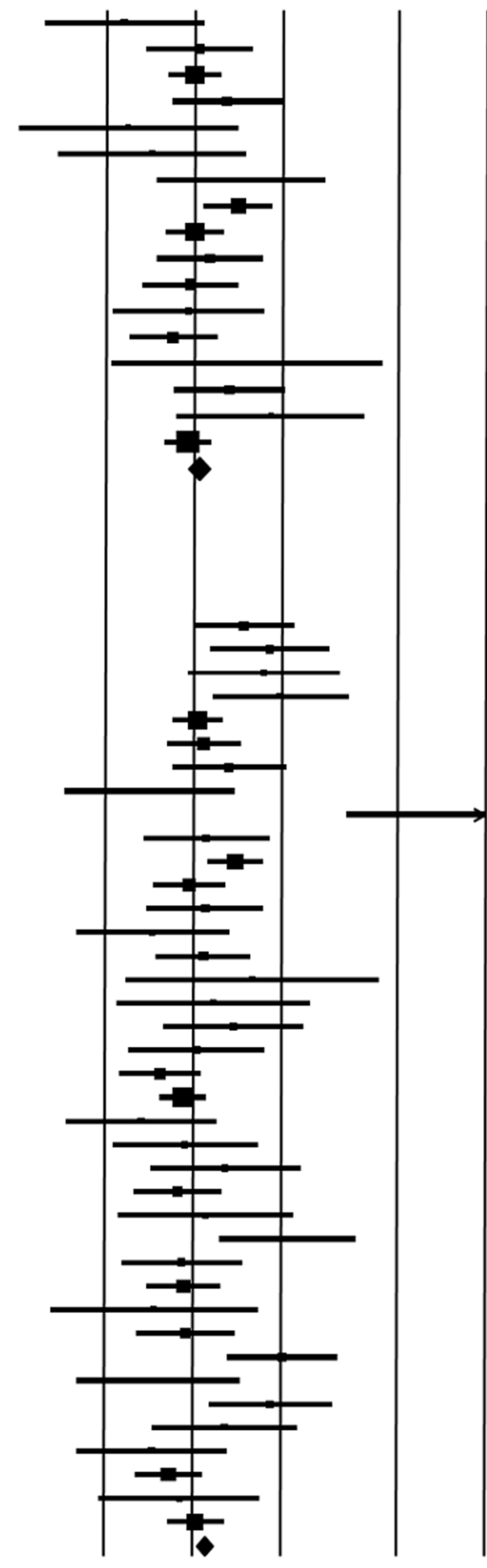

0.5

1

2

5

10

Increased risk of MI for carriers of PIA2 allele

* Studies by Herrmann et al and Kekomaki et al contained distinct population subgroups therefore data processed independently

[OR = odds ratio; $\mathrm{Cl}$ = confidence interval; $\mathrm{MI}=$ myocardial infarction; $\mathrm{CAD}=$ coronary artery disease] 
Figure 5. Analysis of the association between carriage of the PIA2 allele and myocardial infarction based on the use of healthy controls or controls with known coronary artery disease. Analysis is of the PIA1/A1 versus PIA1/A2+PIA2/A2 genotype.

doi:10.1371/journal.pone.0101518.g005

Studies have been inconclusive, with no difference observed in static systems but an enhancement of binding and outside-in signalling seen in cell culture under conditions of shear stress, thus potentially resulting in circulating platelets having a higher basal level of activation [2]. Similarly to plasma lipids, plasma fibrinogen concentration has been suggested as a potential modulator of the increased risk secondary to carriage of the PlA2 allele, but as with the lipid hypothesis, studies included in this meta-analysis do not support this association. Three studies reported a higher levels of fibrinogen in certain subgroups of individuals carrying the PIA2 allele $[85,86,121]$ and two studies reported higher fibrinogen levels in PlAl homozygous subjects [124,125].

Resistance to aspirin has been suggested as another potential mechanism by which carriage of the PlA2 allele may cause increased cardiovascular risk [135]. However, a recent large metaanalysis has suggested that this is not the case [136]. There is however significant inter-study heterogeneity, and the need for further studies in this regard remains.

A final avenue of investigation has been whether the PlA1/A2 antigens affect the degree or morphology of atherosclerosis. Carotid plaque morphology was examined by magnetic resonance imaging in 1,202 participants in the atherosclerotic risk in communities (ARIC) study [46]. Subjects who carried the PlA2 allele were found to have plaques with thinner fibrous caps, and these thinner caps represent the major precursor lesion for ACS [137]. However, this study was limited by a low frequency of the minor allele and technical constraints resulting in plaque morphology being assessed only in individuals with thick arterial walls.

\section{Study limitations}

A potential limitation of this meta-analysis is the presence of a mortality bias that may attenuate or entirely obscure any true association. Almost a third of individuals with a first major coronary event die out-of-hospital [138], and are not accounted for in the predominantly retrospective data presented in this metaanalysis. In fact, in most studies the subject must have survived a cardiac event for a number of months or even years to be available for inclusion. If carriage of the PlA2 allele is more likely to result in an immediately fatal cardiac event then the association would be attenuated, with the opposite effect observed if carriage of the PlAl allele results in increased early mortality.

The potential presence of a mortality bias can be investigated by considering post-mortem data from out-of-hospital deaths. The Helsinki Sudden Death Study considered 700 white Finnish males (aged 33-70 years old) who had sudden, unexpected out-ofhospital deaths [139]. Carriage of the PlA2 allele was significant associated with acute coronary thrombosis in those diagnosed with sudden cardiac death (OR 3.4; 95\% CI 1.5-6.3), with an increased association observed in those $<60$ years old (OR 4.6; 95\% CI $2.0-$ 11.2). These results do suggest the presence of a mortality bias, but the data are not directly comparable to those presented within the present meta-analysis. Nevertheless, they do indicate that carriage of the PlA2 has an increased association with platelet-mediated thrombotic cardiac events, and are therefore consistent with the increased OR seen for the clinical outcome of MI or indeed ACS.

Table 3. Subgroup analyses of the association of carriage of the PIA2 allele and myocardial infarction by study characteristics.

\begin{tabular}{|c|c|c|c|c|c|}
\hline & Number of studies & $\begin{array}{l}\text { Number of } \\
\text { cases/controls }\end{array}$ & $\begin{array}{l}\text { Pooled OR* } \\
(95 \% \mathrm{Cl})\end{array}$ & $\begin{array}{l}\text { Association } \\
\text { (p value) }\end{array}$ & $I^{2}(\%)$ \\
\hline \multicolumn{6}{|c|}{ Subgroup analyses based on control population: } \\
\hline \multirow[t]{2}{*}{ Controls with CAD } & 17 & $10,458 / 19,449$ & 1.024 & 0.583 & 19.1 \\
\hline & {$[80,85,87,88,92-94,96,100,105,106,108,114,118,126-128]$} & & $(0.941-1.114)$ & & \\
\hline \multirow[t]{2}{*}{ Healthy controls } & 39 & $4,883 / 7,016$ & 1.098 & 0.003 & 63.3 \\
\hline & $\begin{array}{l}{[70-73,81-84,87-91,96,98,99,101-104,107,108,110,111,113} \\
115-117,119-124,127,128]\end{array}$ & & $(1.033-1.166)$ & & \\
\hline \multicolumn{6}{|c|}{ Subgroup analyses based on study design: } \\
\hline \multirow[t]{2}{*}{ Cohort } & 17 & $6,192 / 12,840$ & 0.996 & 0.926 & 0.0 \\
\hline & {$[80,85,86,92-95,97,100,105,106,109,112,114,118,125,126]$} & & $(0.917-1.082)$ & & \\
\hline \multirow[t]{2}{*}{ Case-control } & 36 & $10,671 / 10,989$ & 1.126 & $<0.001$ & 66.7 \\
\hline & $\begin{array}{l}{[70-73,81-84,87-91,96,98,99,101-104,107,108,110,111,113} \\
115-117,119-124,127,128]\end{array}$ & & $(1.057-1.198)$ & & \\
\hline \multicolumn{6}{|c|}{ Subgroup analyses based on number of cases: } \\
\hline \multirow[t]{2}{*}{$<250$ cases } & 37 & $6,462 / 3,683$ & 1.240 & 0.006 & 59.2 \\
\hline & $\begin{array}{l}{[70,72,73,80-83,85,88-94,97,98,102,103,105,108,110,111,} \\
113-116,118-127,130]\end{array}$ & & $(1.139-1.350)$ & & \\
\hline \multirow[t]{2}{*}{$\geq 250$ cases } & 17 & $10,401 / 20,146$ & 0.999 & 0.864 & 25.3 \\
\hline & {$[71,72,84,86,87,95,96,99-101,104,106,107,109,112,117,128]$} & & $(0.935-1.084)$ & & \\
\hline
\end{tabular}

*OR (odds ratio) calculated using fixed-effects model for carriage of the PIA2 allele vs PIA1 homozygous subjects.

$[\mathrm{CAD}=$ coronary artery disease].

doi:10.1371/journal.pone.0101518.t003 
Study name

Case-control studies: Anderson et al, 1999

Ardissino et al, 1999

Auguardo et al, 2002

Benze et al, 2002

Bottiger et al, 2000

Carter et al, 1997

Corral et al, 1997

Dayakar et al, 2011

Dogra et al, 2012

Grove et al, 2004

Herrmann et al, 1997*

Herrmann et al, 1997*

Hooper et al, 1999

Joven et al, 1998

Kekomaki et al, 1999*

Kekomaki et al, 1999*

Knowles et al, 2007

Kozieradzka et al, 2006

Kozieradzka et al, 2007

Lagercrantz et al, 2003

Mannucci et al, 2003

Marian et al, 1996

Moshfegh et al, 1999

Motovska et al, 2010

Musino et al, 2010

Osborn et al, 1996

Pastinen et al, 1998

Pegoraro et al, 2005

Ridker et al, 1997

Rosenberg et al, 2002

Samani et al, 1997

Santiago-German et al, 2012

Scaglione et al, 1998

Schwartz et al, 2003

Senti et al, 1998

Tobin et al, 2004

Zotz et al, 1998

Zotz et al, 2005

Subgroup total

Test for heterogeneity: Q-value $=111.202, \mathrm{df}=37(\mathrm{p}<0.001) ;\left.\right|^{2}=66.7 \%$ Test for overall effect: $Z=3.702(p<0.001)$

\section{Cohort studies:}

Addad et al, 2010

Boekholdt et al, 2004

Bojesen et al, 2003

Durante-Mangoni et al, 1998

Faraday et al, 2004

Galasso et al, 2010

Gardemann et al, 1998

Gruchala et al, 2003

Kastrati et al, 2000

Lopez et al, 2004

Mamotte et al, 1998

Marz et al, 2004

Nikolajevic-Starcevic et al, 2012

Park et al, 2004

Rinder et al, 2002

Smith et al, 2003

Walter et al, 2001

Subgroup total

Test for heterogeneity: $Q$-value $=11.841, \mathrm{df}=16(\mathrm{p}=0.755) ;\left.\right|^{2}=0 \%$ Test for overall effect: $Z=-0.092(p=0.926)$
OR (fixed) and $95 \% \mathrm{Cl}$

$\begin{array}{ccc}\text { Odds } & \text { Lower } & \text { Upper } \\ \text { ratio limit } & \text { limit }\end{array}$

$\begin{array}{lll}1.502 & 1.010 \quad 2.233\end{array}$

$\begin{array}{lll}1.843 & 1.154 \quad 2.946\end{array}$

$\begin{array}{lll}1.760 & 0.969 & 3.196\end{array}$

$2.007 \quad 1.177 \quad 3.421$

$\begin{array}{lll}1.060 & 0.791 & 1.421\end{array}$

$\begin{array}{lll}1.660 & 1.151 & 2.393\end{array}$

$\begin{array}{lll}0.717 & 0.367 & 1.398\end{array}$

$\begin{array}{lll}5.935 & 3.398 & 10.366\end{array}$

$1.123 \quad 0.683 \quad 1.845$

$\begin{array}{lll}1.490 & 1.017 \quad 2.183\end{array}$

$\begin{array}{lll}0.975 & 0.736 & 1.292\end{array}$

$\begin{array}{lll}1.110 & 0.702 & 1.754\end{array}$

$\begin{array}{lll}0.733 & 0.401 & 1.341\end{array}$

$\begin{array}{lll}1.092 & 0.756 & 1.579\end{array}$

$\begin{array}{lll}1.609 & 0.595 & 4.351\end{array}$

$\begin{array}{lll}1.185 & 0.555 & 2.529\end{array}$

$\begin{array}{lll}1.260 & 0.975 & 1.628\end{array}$

$\begin{array}{lll}1.385 & 0.800 & 2.397\end{array}$

$\begin{array}{lll}1.035 & 0.607 & 1.765\end{array}$

$\begin{array}{lll}0.776 & 0.565 & 1.065\end{array}$

$\begin{array}{lll}0.929 & 0.777 & 1.109\end{array}$

$\begin{array}{lll}0.945 & 0.520 & 1.719\end{array}$

$\begin{array}{lll}0.912 & 0.493 & 1.688\end{array}$

$\begin{array}{lll}0.993 & 0.548 & 1.800\end{array}$

$\begin{array}{lll}1.298 & 0.719 & 2.341\end{array}$

$\begin{array}{lll}1.109 & 0.559 & 2.202\end{array}$

$\begin{array}{lll}2.110 & 1.238 \quad 3.596\end{array}$

$\begin{array}{lll}0.920 & 0.575 & 1.473\end{array}$

$\begin{array}{lll}0.935 & 0.701 & 1.246\end{array}$

$\begin{array}{lll}1.190 & 0.567 & 2.497\end{array}$

$\begin{array}{lll}0.890 & 0.579 & 1.368\end{array}$

$\begin{array}{lll}2.340 & 1.613 \quad 3.395\end{array}$

$\begin{array}{lll}0.767 & 0.404 & 1.455\end{array}$

$\begin{array}{lll}1.848 & 1.141 & 2.993\end{array}$

$\begin{array}{lll}1.290 & 0.729 & 2.284\end{array}$

$\begin{array}{lll}0.829 & 0.640 & 1.074\end{array}$

$\begin{array}{lll}1.500 & 0.919 & 2.449\end{array}$

$0.940 \quad 0.787 \quad 1.123$

$\begin{array}{lll}1.126 & 1.057 \quad 1.198\end{array}$

\begin{tabular}{ccc}
0.570 & 0.304 & 1.067 \\
1.026 & 0.676 & 1.555 \\
1.048 & 0.859 & 1.279 \\
0.588 & 0.249 & 1.388 \\
0.706 & 0.338 & 1.477 \\
1.428 & 0.740 & 2.755 \\
0.934 & 0.775 & 1.126 \\
1.120 & 0.700 & 1.791 \\
0.993 & 0.795 & 1.239 \\
1.113 & 0.735 & 1.685 \\
0.956 & 0.656 & 1.394 \\
1.090 & 0.869 & 1.368 \\
1.008 & 0.570 & 1.782 \\
0.836 & 0.591 & 1.182 \\
1.500 & 0.517 & 4.352 \\
0.800 & 0.432 & 1.481 \\
1.302 & 0.839 & 2.020 \\
0.996 & 0.917 & 1.082 \\
$841, \mathrm{df}=16(\mathrm{p}=0.755) ;\left.\right|^{2}=0 \%$ \\
$0.926)$ & \multicolumn{2}{l}{}
\end{tabular}

OR (fixed) and $95 \% \mathrm{Cl}$

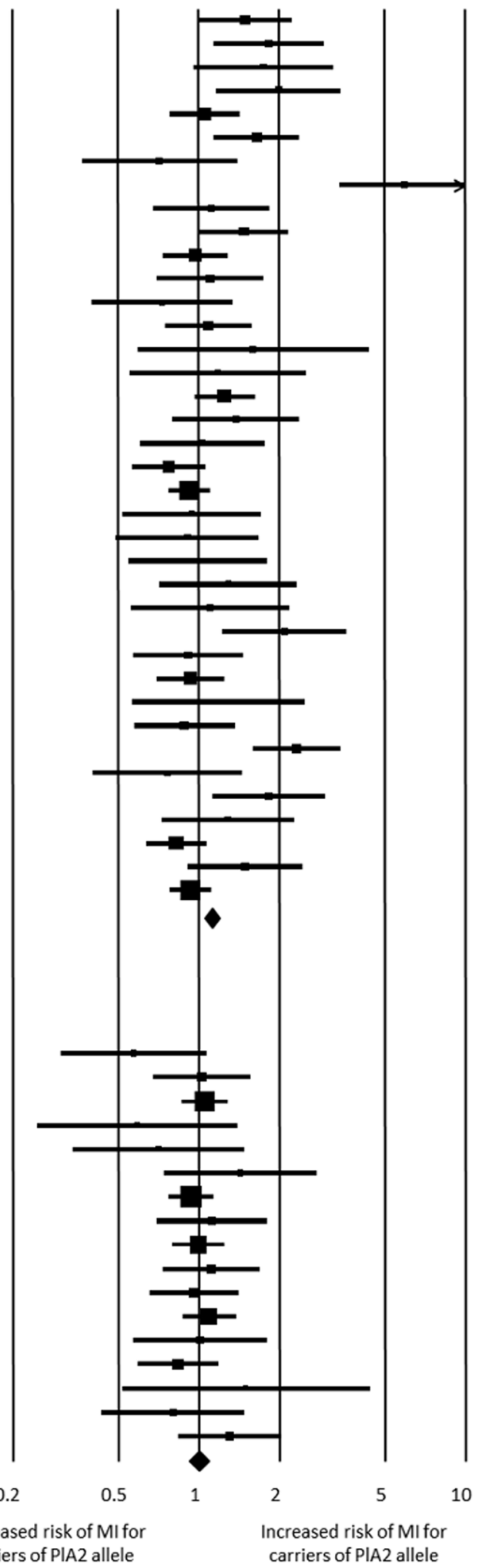

* Studies by Herrmann et al and Kekomaki et al contained distinct population subgroups therefore data processed independently [OR = odds ratio; $\mathrm{Cl}$ = confidence interval; $\mathrm{Ml}=$ myocardial infarction]

Figure 6. Analysis of the association between carriage of the PIA2 allele and myocardial infarction based on study design. Analysis is of the PIA1/A1 versus PIA1/A2+PIA2/A2 genotype.

doi:10.1371/journal.pone.0101518.g006

PLOS ONE | www.plosone.org 

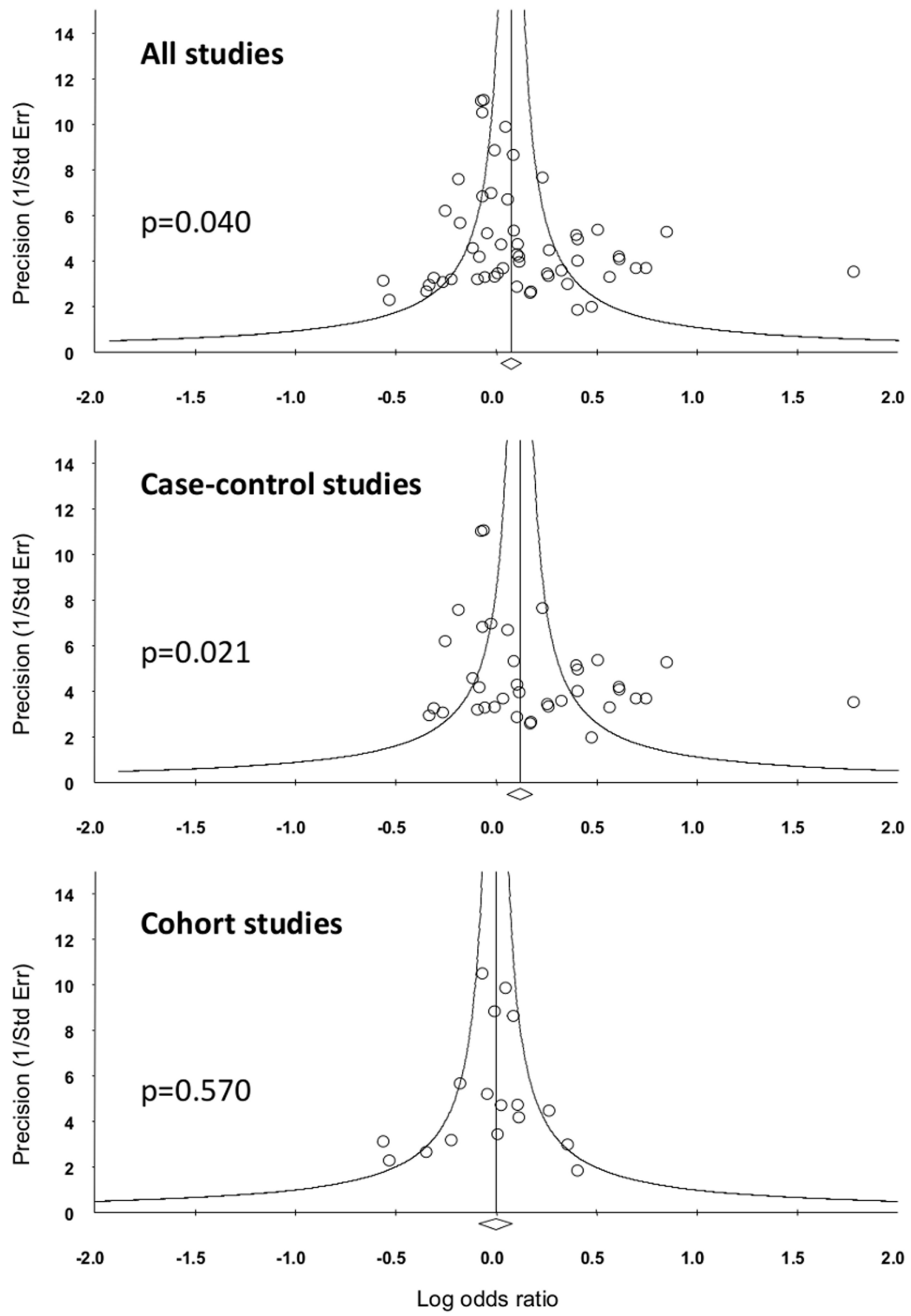
Figure 7. Funnel plots to assess publication bias. For each study, the log odds ratio is shown against study precision. The open diamond below the $x$-axis indicates the pooled odds ratio. $p$-values are reported for Egger's regression intercept, where $p>0.05$ suggests a low probability of publication bias.

doi:10.1371/journal.pone.0101518.g007

\section{Conclusions}

In conclusion, carriage of the PlA2 allele is a significant risk factor for the development of acute coronary events in younger subjects, with data representing the total population subject to significant publication bias. This age-skewed risk profile appears to be the result of the relative impact of the polymorphism becoming attenuated as conventional cardiovascular risk factors develop with advancing age. The precise mechanism by which carriage of the PlA2 allele leads to increased cardiovascular risk remains unclear, however this should not impair its potential utility in risk stratification of younger subjects with modifiable risk factors.

\section{References}

1. Wagner CL, Mascelli MA, Neblock DS, Weisman HF, Coller BS, et al. (1996) Analysis of GPIIb/IIIa receptor number by quantification of 7E3 binding to human platelets. Blood 88: 907-914.

2. Floyd CN, Ferro A (2012) The Platelet Fibrinogen Receptor: from Megakaryocyte to the Mortuary. JRSM - Cardiovascular Disease 1.

3. Newman PJ, Valentin N (1995) Human platelet alloantigens: Recent findings, new perspectives. Thromb Haemost 74: 234-239.

4. Weiss EJ, Bray PF, Tayback M, Schulman SP, Kickler TS, et al. (1996) A polymorphism of a platelet glycoprotein receptor as an inherited risk factor for coronary thrombosis. N Engl J Med 334: 1090-1094.

5. Simsek S, Faber NM, Bleeker PM, Vlekke AB, Huiskes E, et al. (1993) Determination of human platelet antigen frequencies in the Dutch population by immunophenotyping and DNA (allele-specific restriction enzyme) analysis. Blood 81: 835-840.

6. Lim J, Lal S, Ng KC, Ng KS, Saha N, et al. (2003) Variation of the platelet glycoprotein IIIa PI(A1/A2) allele frequencies in the three ethnic groups of Singapore. Int J Cardiol 90: 269-273.

7. Di Castelnuovo A, de Gaetano G, Donati MB, Iacoviello L (2001) Platelet glycoprotein receptor IIIa polymorphism PLA1/PLA2 and coronary risk: a meta-analysis. Thromb Haemost 85: 626-633.

8. Ye Z, Liu EH, Higgins JP, Keavney BD, Lowe GD, et al. (2006) Seven haemostatic gene polymorphisms in coronary disease: meta-analysis of 66,155 cases and 91,307 controls. Lancet 367: 651-658.

9. Lander ES, Schork NJ (1994) Genetic dissection of complex traits. Science 265: 2037-2048.

10. Chiznski K, Roazalski M, Watala C, Golanski J, Golanski R, et al. (2002) Polymorphism P/A of platelet glycorproteins is not a risk factors for ischaemic heart disease and myocardial infarction. Polski Przeglad Kardiologiczny 4: 3540.

11. Chudakova DA, Minushkina LO, Zateishchikov DA, Nosikov VV (2004) Association of polymorphic marker A1/A2 of gene ITGB3 with coronary artery disease and myocardial infarction. [Russian] Assotsiatsiia polimorfnogo markera A1/A2 gena ITGB3 s ishemicheskoi bolezn'iu serdtsa i infarktom miokarda. Genetika 40: 1402-1405.

12. Dankovtseva EN, Zateishchikov DA, Chudakova DA, Koroleva OS, Brovkin AN, et al. (2005) [Associations of hemostasis factors genes with early development of ischemic heart disease and manifestation of myocardial infarction in young age]. Kardiologiia 45: 17-24.

13. Komarova AG, Zotova T, Miandina GI, Kasapova EN, Zotov AK, et al. (2010) [The influence of GPIIIA gene polymorphism on the variability of standard electrocardiogram in patients with acute coronary syndrome]. Klin Med (Mosk) 88: 22-24.

14. Lu L, Yu J, Le W (1999) The relationship between platelet receptor glycoprotein IIIa gene and myocardial infarction in Chinese. [Chinese]. Chinese Journal of Cardiology 27: 111-112.

15. Melus V, Pullmann R, Hybenova J, Skerenova M, Pullmann R, Jr. (1999) [Is PLA1/A2 gene polymorphism of platelet membrane glycoprotein IIIa a risk factor for myocardial infarct?]. Bratisl Lek Listy 100: 593-597.

16. Meshkov AN, Stambol'skii DV, Nikitina LA, Abdullaev SM, Bochkov VN, et al. (2005) [Genetic factors of risk of ischemic heart disease development in patients with familial hypercholesterolemia]. Kardiologiia 45: 10-14.

17. Pavlova TV, Poliakov VP, Dupliakov DV, Khokhlunov SM, Kirillov VI, et al. (2009) [Distributions of polymorphisms of genes of some components of hemostasis in patients with ischemic heart disease]. Kardiologiia 49: 9-13.

18. Pchelina SN, Sirotkina OV, Sheidina AM, Taraskina AE, Rodygina TI, et al. (2007) [Genetic risk factors for development of myocardial infarction in young men living in North-West region of Russia]. Kardiologiia 47: 29-34.

\section{Supporting Information \\ Checklist S1 PRISMA Checklist. \\ (DOC)}

\section{Author Contributions}

Conceived and designed the experiments: CNF AF. Performed the experiments: GNF AM. Analyzed the data: GNF AM. Wrote the paper: GNF AF

19. Tchoudakova DA, Minushkina LO, Zateyshchikov DA, Nosikov VV (2004) Association of polymorphic marker A1/A2 of gene ITGB3 with coronary artery disease and myocardial infarction. [Russian]. Genetika 40: 1402-1405.

20. Tereshchenko SN, Levchuk NN, Drozdov VN, Shaikhaev GO, Leont'ev SG, et al. (1999) [Polymorphism of GPIIIA platelet glycoprotein gene PIA1/A2 compared to plasma hemostasis in myocardial infarction patients]. Ter Arkh 71: 66-70.

21. Yang SL, He BX, He ZY, Zhang H, Zou YC, et al. (2002) Glycoprotein IIIa gene polymorphisms and risk for coronary artery disease in Chinese Urumqi Uygur and Han population. Chinese Journal of Clinical Rehabilitation 6: 3294-3295.

22. Cenarro A, Casao E, Civeira F, Jensen HK, Faergeman O, et al. (1999) P1A1/ A2 polymorphism of platelet glycoprotein IIIa and risk of acute coronary syndromes in heterozygous familial hypercholesterolemia. Atherosclerosis 143: 99-104.

23. Goldschmidt-Clermont PJ, Coleman LD, Pham Y, Cooke GE, Shear WS, et al. (1999) Higher prevalence of GPIIIa PI(A2) polymorphism in siblings of patients with premature coronary heart disease. Archives of Pathology and Laboratory Medicine 123: 1223-1229.

24. Yucel O, Karahan O, Zorlu A, Manduz S (2012) Familial genetic risk factors in premature cardiovascular disease: a family study. Mol Biol Rep 39: 6141-6147.

25. Carter AM, Ossei-Gerning N, Grant PJ (1996) Platelet glycoprotein IIIa PIA polymorphism and myocardial infarction. N Engl J Med 335: 1072-1073; author reply 1073-1074.

26. Cayla G, Scott S, O'Connor S, Hulot JS, Silvain J, et al. (2011) Clinical, angiographic and genetic determinants of early coronary stent thrombosis: The onassist study. Circulation 1).

27. De Rosa R, Galasso G, Piscione F, Santulli G, Iaccarino G, et al. (2010) Increased risk of cardiovascular events associated with the GPIIIA PIA2 polymorphism. Cardiovasc Res 87: S74-S75.

28. Kastrati A, Schomig A, Seyfarth M, Koch W, Elezi S, et al. (1999) PlA polymorphism of platelet glycoprotein IIIa and risk of restenosis after coronary stent placement. Circulation 99: 1005-1010.

29. Martini CH, Doggen CJ, Cavallini C, Rosendaal FR, Mannucci PM (2005) No effect of polymorphisms in prothrombotic genes on the risk of myocardial infarction in young adults without cardiovascular risk factors. J Thromb Haemost 3: 177-179.

30. Todur SP, Kondkar AA, Shalia K, Dalal JJ, Ponde CK, et al. (2010) Association of platelet gene polymorphisms with coronary artery disease in the Indian population. Arteriosclerosis, Thrombosis and Vascular Biology 29 (7): e87.

31. Walter DH, Schachinger V, Elsner M, Dimmeler S, Zeiher AM (1997) Platelet glycoprotein IIIa polymorphisms and risk of coronary stent thrombosis. Lancet 350: $1217-1219$.

32. Abboud N, Amin H, Ghazouani L, Ben Haj Khalifa S, Ben Khalafallah A, et al. (2010) Polymorphisms of human platelet alloantigens HPA-1 and HPA-2 associated with severe coronary artery disease. Cardiovasc Pathol 19: 302-307.

33. Abboud N, Ghazouani L, Ben-Hadj-Khalifa S, Anabi F, Added F, et al. (2010) Human platelet alloantigens HPA-1, HPA-2, and HPA-3 polymorphisms associated with extent of severe coronary artery disease. J Thromb Thrombolysis 29: 409-415.

34. Abu-Amero KK, Wyngaard CA, Dzimiri N (2004) Association of the platelet glycoprotein receptor IIIa (PlA1/PIA1) genotype with coronary artery disease in Arabs. Blood Coagul Fibrinolysis 15: 77-79.

35. Aleksic N, Juneja H, Folsom AR, Ahn C, Boerwinkle E, et al. (2000) Platelet $\mathrm{Pl}(\mathrm{A} 2)$ allele and incidence of coronary heart disease: Results from the atherosclerosis risk in communities (ARIC) study. Circulation 102: 1901-1905. 
36. Ashavaid TF, Todur SP, Kondkar AA, Nair KG, Shalia KK, et al. (2011) Platelet polymorphisms: frequency distribution and association with coronary artery disease in an Indian population. Platelets 22: 85-91.

37. Bray PF, Cannon CP, Goldschmidt-Clermont P, Moye LA, Pfeffer MA, et al. (2001) The platelet Pl(A2) and angiotensin-converting enzyme (ACE) D allele polymorphisms and the risk of recurrent events after acute myocardial infarction. Am J Cardiol 88: 347-352.

38. Jansen ACM, Van Aalst-Cohen ES, Tanck MWT, Cheng S, Fontecha MR, et al. (2005) Genetic determinants of cardiovascular disease risk in familial hypercholesterolemia. Arterioscler Thromb Vasc Biol 25: 1475-1481.

39. Carter AM, Mansfield MW, Grant PJ (1998) Polymorphisms of platelet glycoproteins in relation to macrovascular disease in type 2 diabetes mellitus. Diabet Med 15: 315-319.

40. Cayla G, Hulot JS, O’Connor SA, Pathak A, Scott SA, et al. (2011) Clinical, angiographic, and genetic factors associated with early coronary stent thrombosis. JAMA 306: 1765-1774.

41. Cymbron T, Raposo M, Kazachkova N, Bettencourt C, Silva F, et al. (2011) Cross-sectional study of risk factors for atherosclerosis in the Azorean population. Ann Hum Biol 38: 354-359.

42. Falchi A, Giovannoni L, Piras IS, Calo CM, Moral P, et al. (2005) Prevalence of genetic risk factors for coronary artery disease in Corsica island (France). Exp Mol Pathol 79: 210-213.

43. Garcia-Ribes M, Gonzalez-Lamuno D, Hernandez-Estefania R, Colman T, Pocovi M, et al. (1998) Polymorphism of the platelet glycoprotein IIIa gene in patients with coronary stenosis. Thromb Haemost 79: 1126-1129.

44. Garg UC, Arnett DK, Folsom AR, Province MA, Williams RR, et al. (1998) Lack of association between platelet glycoprotein IIb/IIIa receptor PlA polymorphism and coronary artery disease or carotid intima-media thickness. Thromb Res 89: 85-89.

45. Goodall AH, Curzen N, Panesar M, Hurd C, Knight CJ, et al. (1999) Increased binding of fibrinogen to glycoprotein IIIa-proline33 (HPA-1b, PlA2, Zwb) positive platelets in patients with cardiovascular disease. Eur Heart J 20: $742-$ 747.

46. Kucharska-Newton AM, Monda KL, Campbell S, Bradshaw PT, Wagenknecht LE, et al. (2011) Association of the platelet GPIIb/IIIa polymorphism with atherosclerotic plaque morphology: the Atherosclerosis Risk in Communities (ARIC) Study. Atherosclerosis 216: 151-156.

47. Maksimenko LV, Moiseeva TY, Tugarinova GV, Karpova EV, Frolov VA, et al. (2000) Clinical symptoms of acute coronary insufficiency correlate with GPIIIa genotype of integrin beta-subunit. Bull Exp Biol Med 129: 578-580.

48. McCarthy IJ, Meyer J, Moliterno DJ, Newby LK, Rogers WJ, et al. (2003) Evidence for substantial effect modification by gender in a large-scale genetic association study of the metabolic syndrome among coronary heart disease patients. Hum Genet 114: 87-98.

49. Pamukcu B, Oflaz H, Nisanci Y (2005) The role of platelet glycoprotein IIIa polymorphism in the high prevalence of in vitro aspirin resistance in patients with intracoronary stent restenosis. Am Heart J 149: 675-680.

50. Pellitero S, Reverter JL, Tassies D, Pizarro E, Monteagudo J, et al. (2010) Polymorphisms in platelet glycoproteins Ia and IIIa are associated with arterial thrombosis and carotid atherosclerosis in type 2 diabetes. Thromb Haemost 103: 630-637.

51. Sperr WR, Huber K, Roden M, Janisiw M, Lang T, et al. (1998) Inherited platelet glycoprotein polymorphisms and a risk for coronary heart disease in young central Europeans. Thromb Res 90: 117-123

52. Syros G, Mehran R, Weisz G, Kittas C, Moses JW, et al. (2009) Role of PLA2 polymorphism on clinical events after percutaneous coronary intervention. Acute Card Care 11: 88-91.

53. Var A, Utuk O, Akcal IS, SanlIdag T, UyanIk BS, et al. (2009) Impact of hemostatic gene single point mutations in patients with non-diabetic coronary artery disease. Molecular Biology Reports 36: 2235-2243.

54. Verschuren JJW, Boden H, Wessels JAM, Van Der Hoeven BL, Trompet S, et al. (2012) Value of platelet pharmacogenetics in common clinical practice of patients with ST-segment elevation myocardial infarction. Eur Heart J 33: 516.

55. Volzke H, Grimm R, Robinson DM, Wolff B, Schwahn C, et al. (2004) Candidate genetic markers and the risk of restenosis after coronary angioplasty. Clin Sci (Lond) 106: 35-42.

56. Volzke H, Kleine V, Robinson DM, Grimm R, Hertwig S, et al. (2005) Reninangiotensin system and haemostasis gene polymorphisms and outcome after coronary artery bypass graft surgery. Int J Cardiol 98: 133-139.

57. Yongbin N, Dayi H, Hong Y, Cuilan L, Wenling L, et al. (2004) Association of genetic polymorphisms in the fibrinogen and platelet glycoprotein genes with unstable Angina in Chinese patients. Clin Cardiol 27: 455-458.

58. Aydinalp A, Atar I, Atac FB, Yazici AC, Cicek M, et al. (2010) Glycoprotein IIIa gene polymorphism and coronary artery disease. Acta Cardiol 65: 225230.

59. Barakat K, Kennon S, Hitman GA, Aganna E, Price CP, et al. (2001) Interaction between smoking and the glycoprotein IIIa P1(A2) polymorphism in non-ST-elevation acute coronary syndromes. J Am Coll Cardiol 38: 1639 1643.

60. Brscic E, Bergerone S, Gagnor A, Colajanni E, Matullo G, et al. (2000) Acute myocardial infarction in young adults: prognostic role of angiotensinconverting enzyme, angiotensin II type I receptor, apolipoprotein E, endothelial constitutive nitric oxide synthase, and glycoprotein IIIa genetic polymorphisms at medium-term follow-up. Am Heart J 139: 979-984.
61. French JK, Van de Water NS, Sutton TM, Lund M, Gao W, et al. (2003) Potential thrombophilic mutations/polymorphisms in patients with no flowlimiting stenosis after myocardial infarction. Am Heart J 145: 118-124.

62. Gul I, Kucukdurmaz Z, Kalay N, Karapinar H, Inanc MT, et al. (2012) Polymorphisms of selected genes related to increased cardiovascular risk in patients with acute coronary syndromes and their relation to the severity of coronary artery disease. Postepy w Kardiologii Interwencyjnej 8: 25-30.

63. Laule M, Cascorbi I, Stangl V, Bielecke C, Wernecke KD, et al. (1999) A1/A2 polymorphism of glycoprotein IIIa and association with excess procedural risk for coronary catheter interventions: a case-controlled study. Lancet 353: 708712 .

64. Le Hello C, Morello R, Lequerrec A, Duarte C, Riddell J, et al. (2007) Effect of $\mathrm{PlA} 1 / \mathrm{A} 2$ glycoprotein IIIa gene polymorphism on the long-term outcome after successful coronary stenting. Thromb J 5: 19.

65. Nassar BA, Dunn J, Title LM, O'Neill BJ, Kirkland SA, et al. (1999) Relation of genetic polymorphisms of apolipoprotein $\mathrm{E}$, angiotensin converting enzyme, apolipoprotein B-100, and glycoprotein IIIa and early-onset coronary heart disease. Clin Biochem 32: 275-282.

66. Odeberg J, Freitag M, Odeberg H, Rastam L, Lindblad U (2006) Severity of acute coronary syndrome is predicted by interactions between fibrinogen concentrations and polymorphisms in the GPIIIa and FXIII genes. J Thromb Haemost 4: 909-912.

67. Simon T, Verstuyft C, Mary-Krause M, Quteineh L, Drouet E, et al. (2009) Genetic determinants of response to clopidogrel and cardiovascular events. N Engl J Med 360: 363-375.

68. Zotz RB, Klein M, Dauben HP, Moser C, Gams E, et al. (2000) Prospective analysis after coronary-artery bypass grafting: platelet GP IIIa polymorphism (HPA-1b/PIA2) is a risk factor for bypass occlusion, myocardial infarction, and death. Thromb Haemost 83: 404-407.

69. Morgan TM, Krumholz HM, Lifton RP, Spertus JA (2007) Nonvalidation of reported genetic risk factors for acute coronary syndrome in a large-scale replication study. JAMA 297: 1551-1561.

70. Moshfegh KH, Wuillemin WA (1999) Platelet polymorphisms of GPIa/IIa (Collagen) and GPIIb/IIIa (Fibrinogen) receptors and the risk of myocardial infarction. Thromb haemost 82 (Suppl): 361.

71. Tobin MD, Braund PS, Burton PR, Thompson JR, Steeds R, et al. (2004) Genotypes and haplotypes predisposing to myocardial infarction: a multilocus case-control study. Eur Heart J 25: 459-467.

72. Herrmann SM, Poirier O, Marques-Vidal P, Evans A, Arveiler D, et al. (1997) The Leu33/Pro polymorphism (PlA1/PlA2) of the glycoprotein IIIa (GPIIIa) receptor is not related to myocardial infarction in the ECTIM Study. Etude Cas-Temoins de l'Infarctus du Myocarde. Thromb Haemost 77: 1179-1181.

73. Kekomaki S, Hamalainen L, Kauppinen-Makelin R, Palomaki H, Kaste M, et al. (1999) Genetic polymorphism of platelet glycoprotein IIIa in patients with acute myocardial infarction and acute ischaemic stroke. J Cardiovasc Risk 6: $13-17$.

74. Mantel N, Haenszel W (1959) Statistical aspects of the analysis of data from retrospective studies of disease. J Natl Cancer Inst 22: 719-748.

75. DerSimonian R, Laird N (1986) Meta-analysis in clinical trials. Control Clin Trials 7: 177-188.

76. Borenstein M, Hedges LV, Higgins JPT, Rothstein HR (2009) Introduction to Meta-Analysis John Wiley \& Sons, Ltd.

77. Deeks JJ (2001) Systematic reviews in health care: Systematic reviews of evaluations of diagnostic and screening tests. BMJ 323: 157-162.

78. Higgins JPT, Green S (2008) Cochrane Handbook for Systematic Reviews of Interventions Version 5.0.0: The Cochrane Collaboration.

79. Egger M, Davey Smith G, Schneider M, Minder C (1997) Bias in meta-analysis detected by a simple, graphical test. BMJ 315: 629-634.

80. Addad F, Elalamy I, Chakroun T, Abderrazek F, Dridi Z, et al. (2010) Platelet glycoprotein IIIa (platelet antigen 1/platelet antigen 2) polymorphism and 1year outcome in patients with stable coronary artery disease. Blood Coagul Fibrinolysis 21: 674-678.

81. Anderson JL, King GJ, Bair TL, Elmer SP, Muhlestein JB, et al. (1999) Associations between a polymorphism in the gene encoding glycoprotein IIIa and myocardial infarction or coronary artery disease. J Am Coll Cardiol 33: $727-733$

82. Ardissino D, Mannucci PM, Merlini PA, Duca F, Fetiveau R, et al. (1999) Prothrombotic genetic risk factors in young survivors of myocardial infarction. Blood 94: 46-51.

83. Auguadro G, Mortara A, Priori SG, Specchia G (2002) GPIIb/IIIa polymorphism in patients with myocardial infarction. Acta Cardiol 57: 32-33.

84. Benze G, Heinrich J, Schulte H, Rust S, Nowak-Gottl U, et al. (2002) Association of the GPIa C807T and GPIIIa PlA1/A2 polymorphisms with premature myocardial infarction in men. Eur Heart J 23: 325-330.

85. Boekholdt SM, Peters RJ, de Maat MP, Zwinderman AH, van Der Wall EE, et al. (2004) Interaction between a genetic variant of the platelet fibrinogen receptor and fibrinogen levels in determining the risk of cardiovascular events. Am Heart J 147: 181-186.

86. Bojesen SE, Juul K, Schnohr P, Tybjaerg-Hansen A, Nordestgaard BG (2003) Platelet glycoprotein IIb/IIIa Pl(A2)/Pl(A2) homozygosity associated with risk of ischemic cardiovascular disease and myocardial infarction in young men: the Copenhagen City Heart Study. J Am Coll Cardiol 42: 661-667. 
87. Bottiger C, Kastrati A, Koch W, Mehilli J, Seidl H, et al. (2000) HPA-1 and HPA-3 polymorphisms of the platelet fibrinogen receptor and coronary artery disease and myocardial infarction. Thromb Haemost 83: 559-562.

88. Carter AM, Ossei-Gerning N, Wilson IJ, Grant PJ (1997) Association of the platelet $\mathrm{Pl}(\mathrm{A})$ polymorphism of glycoprotein IIb/IIIa and the fibrinogen Bbeta 448 polymorphism with myocardial infarction and extent of coronary artery disease. Circulation 96: 1424-1431.

89. Corral J, Gonzalez-Conejero R, Rivera J, Iniesta JA, Lozano ML, et al. (1997) HPA-1 genotype in arterial thrombosis-ole of HPA-1b polymorphism in platelet function. Blood Coagul Fibrinolysis 8: 284-290.

90. Dayakar S, Reddy TPK, Rao SP, Sesikeran SB, Sadhnani M (2011) Role of platelet glycoprotein receptor IIIa PIA2 and traditional risk factors in the etiology of coronary thrombosis. Thrombosis Research 128: 595-597.

91. Dogra RK, Das R, Ahluwalia J, Kumar RM, Talwar KK (2012) Prothrombotic gene polymorphisms and plasma factors in young north Indian survivors of acute myocardial infarction. J Thromb Thrombolysis 34: 276-282.

92. Durante-Mangoni E, Davies GJ, Ahmed N, Ruggiero G, Tuddenham EG (1998) Coronary thrombosis and the platelet glycoprotein IIIA gene PLA2 polymorphism. Thromb Haemost 80: 218-219.

93. Faraday N, Martinez EA, Scharpf RB, Kasch-Semenza L, Dorman T, et al. (2004) Platelet gene polymorphisms and cardiac risk assessment in vascular surgical patients. Anesthesiology 101: 1291-1297.

94. Galasso G, Santulli G, Piscione F, De Rosa R, Trimarco V, et al. (2010) The GPIIIA PlA2 polymorphism is associated with an increased risk of cardiovascular adverse events. BMC Cardiovasc Disord 10: 41.

95. Gardemann A, Humme J, Stricker J, Nguyen QD, Katz N, et al. (1998) Association of the platelet glycoprotein IIIa PlA1/A2 gene polymorphism to coronary artery disease but not to nonfatal myocardial infarction in low risk patients. Thromb Haemost 80: 214-217.

96. Grove EL, Orntoft TF, Lassen JF, Jensen HK, Kristensen SD (2004) The platelet polymorphism PlA2 is a genetic risk factor for myocardial infarction. Journal of Internal Medicine 255: 637-644.

97. Gruchala M, Ciecwierz D, Ochman K, Targonski R, Dubaniewicz W, et al. (2003) Association between the $\mathrm{Pl}(\mathrm{A})$ platelet glycoprotein GPIIIa polymorphism and extent of coronary artery disease. Int J Cardiol 88: 229-237.

98. Hooper WC, Lally C, Austin H, Benson J, Dilley A, et al. (1999) The relationship between polymorphisms in the endothelial cell nitric oxide synthase gene and the platelet GPIIIa gene with myocardial infarction and venous thromboembolism in African Americans. Chest 116: 880-886.

99. Joven J, Simo JM, Vilella E, Camps J, Masana L, et al. (1998) Lipoprotein(a) and the significance of the association between platelet glycoprotein IIIa polymorphisms and the risk of premature myocardial infarction. Atherosclerosis 140: 155-159.

100. Kastrati A, Koch W, Gawaz M, Mehilli J, Bottiger C, et al. (2000) PlA polymorphism of glycoprotein IIIa and risk of adverse events after coronary stent placement. J Am Coll Cardiol 36: 84-89.

101. Knowles JW, Wang H, Itakura H, Southwick A, Myers RM, et al. (2007) Association of polymorphisms in platelet and hemostasis system genes with acute myocardial infarction. Am Heart J 154: 1052-1058.

102. Kozieradzka A, Kaminski KA, Pepinski W, Janica J, Korecki J, et al. (2006) The effect of glycoprotein IIIa A1/A2 gene polymorphism on one-year outcome in patients with ST-segment elevation myocardial infarction treated with primary percutaneous coronary intervention. Kardiol Pol 64: 1350-1355; discussion 1356

103. Kozieradzka A, Kaminski K, Pepinski W, Janica J, Korecki J, et al. (2007) The association between type 2 diabetes mellitus and A1/A2 polymorphism of glycoprotein IIIa gene. Acta Diabetol 44: 30-33

104. Lagercrantz J, Bergman M, Lundman P, Tornvall P, Hjemdahl P, et al. (2003) No evidence that the PLA1/PLA2 polymorphism of platelet glycoprotein IIIa is implicated in angiographically characterized coronary atherosclerosis and premature myocardial infarction. Blood Coagul Fibrinolysis 14: 749-753.

105. Lopes NH, Pereira AC, Hueb W, Soares PR, Lanz JR, et al. (2004) Effect of glycoprotein IIIa PlA2 polymorphism on outcome of patients with stable coronary artery disease and effect of smoking. Am J Cardiol 93: 1469-1472.

106. Mamotte CD, van Bockxmeer FM, Taylor RR (1998) PIa1/a2 polymorphism of glycoprotein IIIa and risk of coronary artery disease and restenosis following coronary angioplasty. Am J Cardiol 82: 13-16.

107. Mannucci PM, Merlini PA, Ardissino D, Barzuini C, Bernardi F, et al. (2003) No evidence of association between prothrombotic gene polymorphisms and the development of acute myocardial infarction at a young age. Circulation 107: $1117-1122$.

108. Marian AJ, Brugada R, Kleiman NS (1996) Platelet glycoprotein IIIa PlA polymorphism and myocardial infarction. N Engl J Med 335: 1071-1072; author reply $1073-1074$

109. Marz W, Boehm BO, Winkelmann BR, Hoffmann MM (2004) The PlA1/A2 polymorphism of platelet glycoprotein IIIa is not associated with the risk of type 2 diabetes. The Ludwigshafen Risk and Cardiovascular Health study. Diabetologia 47: 1969-1973.

110. Motovska Z, Kvasnicka J, Hajkova J, Kala P, Simek S, et al. (2010) Platelet gene polymorphisms and risk of bleeding in patients undergoing elective coronary angiography: a genetic substudy of the PRAGUE-8 trial. Atherosclerosis 212: 548-552.
111. Musino L, Rossi R, Partenza A, Mureddu G, Zinellu A, et al. (2010) Hemostatic gene polymorphisms in young Sardinian with non-fatal acute myocardial infarction. Front Biosci (Elite Ed) 2: 559-565.

112. Nikolajevic-Starcevic J, Petrovic D (2012) The al/a2 polymorphism of the glycoprotein IIIa gene and myocardial infarction in Caucasians with type 2 diabetes. Mol Biol Rep.

113. Osborn SV, Hampton KK, Smillie D, Channer KS, Daly ME (1996) Platelet glycoprotein IIIa gene polymorphism and myocardial infarction. Lancet 348 : 1309-1310.

114. Park S, Park HY, Park C, Ko YG, Im EK, et al. (2004) Association of the gene polymorphisms of platelet glycoprotein Ia and IIb/IIIa with myocardial infarction and extent of coronary artery disease in the Korean population. Yonsei Med J 45: 428-434.

115. Pastinen T, Perola M, Niini P, Terwilliger J, Salomaa V, et al. (1998) Arraybased multiplex analysis of candidate genes reveals two independent and additive genetic risk factors for myocardial infarction in the Finnish population. Hum Mol Genet 7: 1453-1462.

116. Pegoraro RJ, Ranjith N (2005) Plasminogen activator inhibitor type 1 (PAI-1) and platelet glycoprotein IIIa (PGIIIa) polymorphisms in young Asian Indians with acute myocardial infarction. Cardiovasc J S Afr 16: 266-270.

117. Ridker PM, Hennekens CH, Schmitz C, Stampfer MJ, Lindpaintner K (1997) PIA1/A2 polymorphism of platelet glycoprotein IIIa and risks of myocardial infarction, stroke, and venous thrombosis. Lancet 349: 385-388.

118. Rinder CS, Mathew JP, Rinder HM, Greg Howe J, Fontes M, et al. (2002) Platelet PlA2 polymorphism and platelet activation are associated with increased troponin I release after cardiopulmonary bypass. Anesthesiology 97: 1118-1122.

119. Rosenberg N, Zivelin A, Chetrit A, Dardik R, Kornbrot N, et al. (2002) Effects of platelet membrane glycoprotein polymorphisms on the risk of myocardial infarction in young males. Isr Med Assoc J 4: 411-414.

120. Samani NJ, Lodwick D (1997) Glycoprotein IIIa polymorphism and risk of myocardial infarction. Cardiovasc Res 33: 693-697.

121. Santiago-German D, Leanos-Miranda A, Garcia-Latorre E, Borrayo-Sanchez G, Majluf-Cruz A, et al. (2012) Platelet glycoprotein IIIA PIA2 polymorphism is associated with ST elevation acute myocardial infarction in young Mexican population. J Thromb Thrombolysis 33: 389-396.

122. Scaglione L, Bergerone S, Gaschino G, Imazio M, Maccagnani A, et al. (1998) Lack of relationship between the P1A1/P1A2 polymorphism of platelet glycoprotein IIIa and premature myocardial infarction. Eur J Clin Invest 28: 385-388.

123. Schwartz E, Demidova D, Sirotkina O, Kudinov S (2003) The combination of glycoprotein IIIa PlA polymorphism with polymorphism of serotonin transporter as an independent strong risk factor for the occurrence of coronary thrombosis. Mol Genet Metab 79: 229-230.

124. Senti M, Aubo C, Bosch M, Pavesi M, Pena A, et al. (1998) Platelet glycoprotein IIb/IIIa genetic polymorphism is associated with plasma fibrinogen levels in myocardial infarction patients. The REGICOR Investigators. Clin Biochem 31: 647-651.

125. Smith FB, Connor JM, Lee AJ, Cooke A, Lowe GD, et al. (2003) Relationship of the platelet glycoprotein PlA and fibrinogen T/G+1689 polymorphisms with peripheral arterial disease and ischaemic heart disease. Thromb Res 112: 209216.

126. Walter DH, Schachinger V, Elsner M, Mach S, Dimmeler S, et al. (2001) Statin therapy is associated with reduced restenosis rates after coronary stent implantation in carriers of the $\mathrm{Pl}(\mathrm{A} 2)$ allele of the platelet glycoprotein IIIa gene. Eur Heart J 22: 587-595.

127. Zotz RB, Winkelmann BR, Nauck M, Giers G, Maruhn-Debowski B, et al. (1998) Polymorphism of platelet membrane glycoprotein IIIa: human platelet antigen $1 \mathrm{~b}$ (HPA-1b/PlA2) is an inherited risk factor for premature myocardial infarction in coronary artery disease. Thromb Haemost 79: 731-735.

128. Zotz RB, Winkelmann BR, Muller C, Boehm BO, Marz W, et al. (2005) Association of polymorphisms of platelet membrane integrins alphaIIbbeta 3 (HPA-1b/PlA2) and alpha2betal (alpha2807TT) with premature myocardial infarction. Journal of Thrombosis and Haemostasis 3: 1522-1529.

129. Araujo F, Santos A, Araujo V, Henriques I, Monteiro F, et al. (1999) Genetic risk factors in acute coronary disease. Haemostasis 29: 212-218.

130. Herrmann SM, Poirier O, Marques-Vidal P, Evans A, Arveiler D, et al. (1997) The Leu33/Pro polymorphism (Pl(A1)/Pl(A2)) of the glycoprotein IIIa (GPIIIa) receptor is not related to myocardial infarction in the ECTIM study. Thromb Haemost 77: 1179-1181.

131. Marenberg ME, Risch N, Berkman LF, Floderus B, de Faire U (1994) Genetic susceptibility to death from coronary heart disease in a study of twins. N Engl J Med 330: 1041-1046.

132. Nora JJ, Lortscher RH, Spangler RD, Nora AH, Kimberling WJ (1980) Genetic-pidemiologic study of early-onset ischemic heart disease. Circulation 61: 503-508.

133. Senti M, Aubo G, Bosch M (1998) Preliminary report: The relationship between smoking and triglyceride- rich lipoproteins is modulated by genetic variation in the glycoprotein IIIa gene. Metabolism 47: 1040-1041.

134. Larsen GK, Seth M, Gurm HS (2013) The ongoing importance of smoking as a powerful risk factor for ST-segment elevation myocardial infarction in young patients. JAMA Intern Med 173: 1261-1262.

135. Undas A, Brummel K, Musial J, Mann KG, Szczeklik A (2001) Pl(A2) polymorphism of beta(3) integrins is associated with enhanced thrombin 
generation and impaired antithrombotic action of aspirin at the site of microvascular injury. Circulation 104: 2666-2672.

136. Floyd CN, Ferro A (2014) The PlA1/A2 Polymorphism of Glycoprotein IIIa in Relation to Efficacy of Antiplatelet Drugs: a Systematic Review and Metaanalysis. Br J Clin Pharmacol 77: 446-457.

137. Kolodgie FD, Burke AP, Farb A, Gold HK, Yuan J, et al. (2001) The thin-cap fibroatheroma: a type of vulnerable plaque: the major precursor lesion to acute coronary syndromes. Curr Opin Cardiol 16: 285-292.
138. Dudas K, Lappas G, Stewart S, Rosengren A (2011) Trends in out-of-hospital deaths due to coronary heart disease in Sweden (1991 to 2006). Circulation 123: $46-52$.

139. Mikkelsson J, Perola M, Laippala P, Penttila A, Karhunen PJ (2000) Glycoprotein IIIa Pl(A1/A2) polymorphism and sudden cardiac death. J Am Coll Cardiol 36: 1317-1323.

140. Carter AM, Ossei-Gerning N, Grant PJ (1996) Platelet glycoprotein IIIa PlA polymorphism in young men with myocardial infarction. Lancet 348: 485-486. 